\title{
Somerset: Lord Mansfield and the Legitimacy of Slavery in the Anglo-American World*
}

\author{
William M. Wiecek†
}

At Westminster on June 22, 1772, Lord Mansfield, Chief Justice of King's Bench, the highest common law court in England, delivered a brief oral opinion in the case of Somerset $v$. Stewart. ${ }^{1}$ James Somerset, a black alleged to be the runaway slave of Charles Stewart, had sought a writ of habeas corpus to prevent Stewart from seizing and detaining him in England for shipment to Jamaica to be sold. As reported by Capel Lofft, ${ }^{2}$ Mansfield held:

$[T]$ he only question before us is, whether the cause on the return [to the writ] is sufficient? If it is, the negro must be remanded; if it is not, he must be discharged. Accordingly, the return states, that the slave departed and refused to serve; whereupon he was kept, to be sold abroad. So high an act of dominion must be recognized by the law of the country where it is used. The power of a master over his slave has been extremely different, in different countries. The state of slavery is of such a nature, that it is incapable of being introduced on any reasons, moral or political; but only positive law, which preserves its force long after the reasons, occasion, and time itself from whence it was created, is erased from memory: It's so odious, that nothing can be suffered to support it but positive law. Whatever inconveniences, therefore, may follow from a decision, I cannot say this case is allowed or approved

* An early version of this paper was presented at a conference on the law of slavery at The University of Chicago Law School on January 25, 1974. I wish to thank the organizers and participants for criticism and suggestions. I must also express my great indebtedness to Professor David Brion Davis of Yale University, whose draft paper presented at that conference was the source of invaluable leads to evidence, particularly the Granville Sharp transcripts in the New-York Historical Society.

$\dagger$ Associate Professor of History, University of Missouri-Columbia.

1. Lofft 1, 98 Eng. Rep. 499 (K.B. 1772).

2. There is some question about precisely what Mansfield said. For purposes of this paper, I adopt Capel Lofft's version as canonical. My reasons for doing so are set forth in the Appendix, along with a survey of the variant reports of Mansfield's opinion and the attendant controversy. See text and notes at notes 224-40 infra. 
by the law of England; and therefore the black must be discharged. ${ }^{3}$

Mansfield thereby laid down a landmark opinion in Anglo-American jurisprudence, and one that epitomized many characteristics and problems of the judge-made law of slavery.

This law, as developed by English and American jurists, had a curiously indeterminate quality; it was more often than not ambiguous and equivocal. Grounded on shifting considerations of public policy or jurisprudential theory, enunciated by men whose opinions spanned the entire spectrum of pro- and antislavery beliefs, and above all misunderstood by contemporaries and later generations, the case law of slavery evolved in striking contrast with the statutes governing slaves. The latter generally consisted of clear and specific "thou-shalts" and "thou-shalt-nots" regulating the minutiae of behavior of whites and blacks alike. It is one of the paradoxes of slavery in the Anglo-American experience, however, that this iron structure rested on such an uncertain jurisprudential foundation.

No other decision so well illustrates the ambiguities of slave case law as Somerset. No other English decision on slavery has been so often quoted and almost as often misunderstood; no comparable opinion has proliferated such a case law progeny with such protean interpretations. Somerset best illustrates a legal world where things are not what they seem, a world of deceptive appearances and unforeseen consequences.

Technically considered, the judgment in Somerset settled only two narrow points of English law: a master could not seize a slave and remove him from the realm against the slave's will, and a slave could secure a writ of habeas corpus to prevent that removal. Yet many contemporaries, as well as historians, ${ }^{4}$ thought Somerset abolished slavery in England; a few thought it challenged slavery in the colonies as well. Mansfield's utterances had a plangent quality, suggesting that slavery could not legitimately exist anywhere; or, less expansively, that where slavery was established it existed in derogation of natural rights. English writers, displaying

3. Lofft at 19, 98 Eng. Rep. at 510.

4. The contemporaries will be discussed below. For examples of historians' interpretations, see D. Dumond, Antislavery: The Crusade for Freedom in America 5 (1961); Lynd, Rethinking Slavery and Reconstruction, 50 J. Negro Hisr. 198, 201 (1965); Martin, The English Slave Trade and the African Settlements, in 1 THe Cambridge History of the British Empire: The Old EMpire, From the Beginnings to 1783, at 449 (J. Rose et al. eds. 1929). On the origins and prevalence of their misunderstanding, see F. SHYLLON, BLACK SLAVES IN BRITAIN ix-x (1974). 
what Winthrop Jordan has called "that preening consciousness of the peculiar glories of English liberties,"5 quickly adopted the more sweeping interpretation, leading Benjamin Franklin, in London at the time, to write home in disgust to Anthony Benezet about "the hypocrisy of this country, which encourages such a detestable commerce by laws for promoting the Guinea trade; while it piqued itself on its virtue, love of liberty, and the equity of its courts, in setting free a single negro."

Though Mansfield and other jurists subsequently disavowed these broad implications, the decision as reported by Capel Lofft took on a life of its own and entered the mainstream of American constitutionalism. Somerset furnished abolitionists with some of the most potent ideological weapons in their arsenal. At first, even slave state jurists accepted its antislavery premises; when they could do so no longer, they worked out justifications of slavery that explained away or repudiated the case. Thus Somerset became a cloud over the legitimacy of slavery in America, a result that would have surprised and annoyed Mansfield.

Somerset is a fascinating milestone in Anglo-American legal history for reasons other than its tantalizing obscurity and protean potential. It had a lasting impact on American conflict of law theory. It reflected changing conceptions of the jus gentium and influenced the development of interstate relations in the American federal system. It revitalized notions of natural or fundamental law and infused them into American case law. It posed basic constitutional problems for the British imperial system, though these became irrelevant four years later with the declaration of American independence. It was a significant judicial expansion of the scope of habeas corpus and a benchmark in the development of the law of personal liberty.

\section{I}

Since Englishmen commanded slavers by the mid-sixteenth century and soon peopled English New World colonies with African slaves, the early intrusion of slavery issues into English jurisprudence was certain. When English courts were first confronted with slavery cases in the seventeenth century, they turned up a broad array of questions that had to be resolved within the familiar

5. W. Jordan, White Over Black: Aimerican Attitudes Toward the Negro, 15501812 , at 49 (1968).

6. Letter from Benjamin Franklin to Anthony Benezet, Aug. 22, 1772, in 5 THE Writings of Benjamin Franklin 431-32 (A. Smyth ed. 1907): 
forms of the common law, with little guidance from Parliament or the Privy Council: Did slavery have an adequate foundation in the indigenous law of England? If not, had it been interjected into the English legal order through colony slave laws? What were the status and rights of West Indian slaves and masters coming to the metropolis? Could the slave claim any rights under English law? Was a contract for the sale of a slave enforceable in English courts?

If pre-1772 English precedents on slavery were not in hopeless disagreement on these questions, ${ }^{7}$ they did at least suggest several different directions in which the law of slavery might evolve. For example, the earliest reported judicial determination on slavery (as opposed to decisions concerning villeinage, which fill the Plea Rolls and the Yearbooks ${ }^{8}$ ) seemingly accommodated the peculiar character of property in slaves to the familiar forms of English law. In Butts v. Penny, ${ }^{9}$ the plaintiff brought an action in trover for one hundred Negroes taken by the defendant. Trover, a form of action in common law pleading that would lie for recovery of damages for the wrongful taking and detainer of specific chattels, required plaintiffs to have a property right in the chattels. ${ }^{10}$ The decision in Butts turned on this question. The justices of King's Bench held that there might be property rights in slaves sufficient to maintain trover. The court also suggested two theories of the origins of slavery that might accommodate it to English law: Negroes were "infidels";"11 and, more importantly, they were "usually being bought and sold among Merchants, as Merchandise . . . ."12

7. Fiddes, Lord Mansfield and the Sommersett Case, 50 L.Q. Rev. 499 (1934), argues that they were.

8. For a discussion of the legal system of villeinage, see P. Vinogradoff, Villainage [sic] in ENGLand: Essays in ENGlish Mediaeval History, at chs. i-iv (1892). The preElizabethan poor laws contained a short-lived experiment with domestic slavery for vagabonds. 1 Edw. 6, c. 3 (1547), repealed by 3 \& 4 Edw. 6, c. 16 (1551); see Davies, Slavery and Protector Somerset: The Vagrancy Act of 1547, 19 Econ. Hist. Rev., 2d ser. 533-49 (1966) (I am grateful to Professor Stanley Engerman for calling this article to my attention). One unreported sixteenth century precedent, Carturight's Case (1569), was said to have held that "England was too pure an Air for Slaves to breath in." Quoted from $2 \mathrm{~J}$. RusHworTH, Historical Collections 468, reprinted in I H. Catterall, Judicial Cases Concerning american Slavery and the Negro 9 (1926).

9. 2 Lev. 201, 83 Eng. Rep. 518 (K.B. 1677). I am indebted to my colleague Professor William F. Fratcher of the Law School, University of Missouri-Columbia, for assistance in dating cases prior to the mid-eighteenth century and for other valuable assistance.

10. 1 J. Chitty, Pleading 148 (8th Am. ed., J. Dunlap ed. 1840).

11. This point was reiterated and extended in Gelly $v$. Cleve, an unreported 1693 decision quoted in the report of Chamberlain v. Harvey, 1 Ld. Raym. 146, 91 Eng. Rep. 994 (K.B. 1697). Gelly stated not only that a man may have property in Negroes because they are "heathens" but also that a court will take judicial notice of that status.

12. 2 Lev. 201, 83 Eng. Rep. 518 (K.B. 1677). 
It is significant that Mansfield, the great exponent of the law merchant in the following century, chose not to recognize this particular custom of the merchants as a legitimating foundation for slavery. Perhaps his reason was that Butts v. Penny was a shaky precedent. ${ }^{13}$ The judgment for the plaintiff was nisi causa, that is, no judgment at all. In effect, the court held the case over at the request of the Attorney General, who wanted to intervene. No record exists of a subsequent final judgment in the case, so in reality it had no precedential value; but this did not prevent later courts from citing it. Further complicating its status was a problem common to all seventeenth-century decisions, the informal character of the reporting. This problem was not resolved by reliable, quasi-stenographic reporting until the nineteenth century.

Butts v. Penny and the other pre-Somerset cases also demonstrate the truth of the old legal adage that the development of substantive law emerges from the interstices of adjective law. The result in many of the early cases turned, technically, on issues of common law pleading. In Butts, where the question was whether trover was the appropriate form of action for recovery of a group of Negro slaves, counsel ingeniously used that issue to canvass the substantive question of whether it was possible to hold property in man. Likewise, amid seemingly irrelevant quibbles about the quiddities of writs like trespass per quod servitium amisit and declarations pro gallico suo, later cases built up a substantive law that was to determine whether one man could call another man his thing. Or, as Serjeant Glynn put it in his Somerset argument, "upon what Principle is it-can a Man become a Dog for another Man[?]"14

King's Bench was again drawn into the legal controversy over slavery in Chamberlain v. Harvey. ${ }^{15}$ Chief Justice Sir John Holt rejected the doctrine of Butts, stating flatly that neither trover nor an ordinary action in trespass would lie for the taking of a slave. He suggested that the master's proper remedy was trespass per quod servitium amisit, an old declaration claiming loss of the services of a servant. The distinction was more than technical. Trover

13. It was so regarded by English judges and lawyers between Butts and Somerset. See Smith v. Gould, 2 Ld. Raym. 1274, 92 Eng. Rep. 338 (K.B. 1706); Chamberline v. Harvey, 5 Mod. 186, 87 Eng. Rep. 598 (K.B. 1697).

14. Quoted in a transcript of oral argument in Granville Sharp Transcripts, New-York Historical Society, New York City, New York [hereinafter cited as Sharp Trans. NYHS].

15. Three reports of this case exist: Carthew 396, 90 Eng. Rep. 830; 5 Mod. 186, 87 Eng. Rep. 598 (sub nom. Chamberline v. Harvey); 1 Ld. Raym. 146, 91 Eng. Rep. 994 (K.B. 1697). Pleadings and special verdict are in 92 Eng. Rep. 603, under the alternate spelling. I adopt the report of Holt's decision from $1 \mathrm{Ld}$. Raym. and the report of arguments of counsel from 5 Mod. because they are respectively the fuller accounts. 
would treat the slave as a chattel, a thing so utterly unfree that it was vendible; trespass per quod servitium amisit would liken the slave to a bound or apprenticed laborer, "a slavish servant," a human being whose freedom was restricted but not annihilated.

The facts underlying this case, together with the arguments of counsel, ${ }^{16}$ give the case a greater historic significance than its holding alone might suggest. The slave in question had been owned originally in Barbados, where a slave was legally a part of real estate, rather than a chattel. He had been brought to England and baptized there. Counsel seized on these circumstances to explore the law of slavery and to begin unraveling the implications of the imperial relation. In that sense, Chamberlain $v$. Harvey was a direct predecessor of Somerset.

Plaintiff's counsel first contended that "though the word 'slave' has but a very harsh sound in a free and christian country," it could nonetheless exist there, legitimated by a quasi-contract under which the master derived "power" over the slave in return for providing him with food and clothing. ${ }^{17}$ As his argument progressed, it illustrated two common features of the slavery cases. First, he attempted to derive an English law of slavery from the old law of villeinage. (Though villeinage was extinct by the late seventeenth century, lawyers on both sides of any question relating to slavery frequently drew upon precedents or analogies from the legal incidents of this feudal institution.) The peculiar feature of Barbadian law making a slave realty, counsel insisted, made a Barbadian slave the legal equivalent of a villein regardant (a villein attached to the manor, as opposed to a villein in gross, who was attached to the person of his lord). A villein regardant had to be formally manumitted (freed) by his lord, and this slave had not been. Any manumission here would have to be implied or constructive, either from the slave's having been brought to England or having been baptized.

Second, counsel explored contemporary policy considerations that buttressed the outdated technicalities of his arguments. Such considerations, which lurked just under the surface of all the slavery cases, often emerged frankly, as they did here when plaintiff's counsel claimed that baptism should not work an automatic manumission because "it would very much endanger the trade of the plantations, which cannot be carried on without the help and labour of these slaves."

16. The facts and arguments are reported at length at 5 Mod. 182 (K.B. 1697).

17. For a later example of the justification of slavery on grounds of implied contract, see 2 E. Long, The History of Jamarca 393-94 (1774). 
Opposing counsel took higher ground in several points of his argument. First, he insisted that slavery was contrary to "the law of nature." Though this fact did not illegitimate it per se, he continued, the traditional thrust of the common law was in favor of liberty, and presumptions about personal status had to run in favor of freedom. ${ }^{18}$ Thus, slavery could exist only by "the constitution of nations." Defense counsel also argued that in England one could not have absolute property in another man, "because by Magna Charta, and the laws of England, no man can have such a property over another." Finally, he contended that the law making this particular individual a slave was merely lex loci, whose force dissolved when the slave was removed from the jurisdiction or when the slave was baptized, at which point the slave "should thereby acquire the privileges and immunities enjoyed by those of the same religion, and be intitled to the laws of England." Striking though this line of argument was, it was in no way reflected in the constricted opinion of Chief Justice Holt.

Shortly thereafter, Holt handed down two more opinions adverse to the establishment of slavery in England. In Smith v. Brown and Cooper, ${ }^{19}$ Holt took up the issue of the status of a slave coming to England and announced that "as soon as a negro comes into England, he becomes free; one may be a villein in England, but not a slave."20 He was seconded by his colleague Justice Powell, who said "the law took no notice of a negro," an ambiguous statement that in context seemed to mean that English law did not recognize slavery based on race alone. Holt's decision is sometimes read to have abolished slavery in England, ${ }^{21}$ or to have laid down an interpretation of metropolitan law with which colonial slave law was inconsistent. ${ }^{22}$ Both interpretations impose on this case a weight of authority it cannot bear. For one thing, it was hardly a ringing antislavery declaration; in dialogue with counsel, Holt was at pains to suggest a procedural mode by which the claimant in this action of indebitatus assumpsit might recover the value of the slave sold. The effect of this qualification was to preserve a legal

18. This notion, as it related to slavery, had crystallized by the fifteenth century in $\mathrm{J}$. Fortescue, De Laudibus Legum Angliae (S. Chrimes transl. 1942): "Servitude was introduced by men for vicious purposes. But freedom was instilled in human nature by God. . . . The laws of England favour liberty in every case." Id. at 105.

19. 2 Salk. 666, 91 Eng. Rep. 566 (K.B. 1701). The case is also reported at Holt K.B. 495, 90 Eng. Rep. 1172 (K.B. 1701).

20. 2 Salk. at 666, 91 Eng. Rep. at 566; Holt K.B. at 495, 90 Eng. Rep. at 1172.

21. Fratcher, Sovereign Immunity in Probate Proceedings, 31 Mo. L. Rev. 127, 139 (1966).

22. A. Sutherland, Constitutionalism in America: Origin and Evolution of its Fundamental IdeAs 129 (1965). 
mechanism for selling slaves in England. More importantly, as in Butts, there was really no judgment here, and the precedential value of Smith $v$. Brown and Cooper is therefore dubious. The case had come up to King's Bench on a motion in arrest of judgment. The Attorney General, intervening, raised a technicality concerning the hereditable status of slaves in Virginia that so muddled the contractual aspects of the case that, in the laconic observation of Salkeld, "nothing was done."

Holt and his colleagues returned to the subject a few years later in Smith v. Gould ${ }^{23}$ and spoke even more ambivalently. Stating categorically that trover would not lie for a Negro because men could not be "the subject of property" (and explicitly stating Butts $v$. Penny was "not law"), the court nonetheless suggested a way for one claiming a slave to assert his title. Although trover de gallico suo would not work to assert title to a slave obtained through captivity in war, the writ of trespass with the declaration per quod servitium amisit or quare captivum suum cepit could do the same thing, and could also protect the title to a Negro acquired through purchase. Counsel, in wide-ranging arguments, had suggested that men might be "merchandize" like monkeys and that a Negro was not "liber homo." The court's suggestion about trespass quare captivum suum cepit indirectly supported those ideas. It was also consistent with counsel's suggestion that, though slavery did not confer an unqualified or absolute property right, it conveyed a limited right "ex instituto." That argument potentially could have accommodated much of slavery to the law of the realm, and all of it to the law of the colonies.

At this point in the development of ideas about the legitimacy of slavery, the scene of argument shifted from Westminster Hall to the refectory of Lincoln's Inn. One evening in 1729 over afterdinner wine, the members of the Inn solicited Attorney General Philip Yorke and Solicitor General Charles Talbot for their opinions on the effect of baptizing Negro slaves in the plantations. In this congenial setting, Yorke and Talbot delivered a joint opinion firmly and clearly asserting the following points:

1) a slave coming to Great Britain from the West Indies, with or without his master, was not liberated;

2) the master's property right in that slave in Great Britain was not "determined or varied;"

23. This case was twice reported: 2 Salk. 666, 91 Eng. Rep. 567 (K.B. 1705); 2 Ld. Raym. 1274, 92 Eng. Rep. 338 (K.B. 1706). 
3) baptism did not liberate the slave or change his temporal condition; and

4) "the master may legally compel him to return again to the plantations." 24

One of the opinion's authors, Yorke, enjoyed a high reputation for legal acumen, and it survived long enough to provoke Granville Sharp to his first great published effort on behalf of the slaves forty years later.

The Yorke-Talbot position could not, of course, have overruled a clear decision of King's Bench, had there been one; and the informal circumstances of its delivery made it something less than an impregnable bastion for the West India Interest. ${ }^{25}$ Yorke, ennobled and elevated to the woolsack, tried to remedy that insufficiency in Pearne v. Lisle, ${ }^{26}$ a decision he rendered as Hardwicke, Lord Chancellor. Grandly waving away all of Holt's handiwork (through a clearly insupportable construction of Smith $v$. Brown and Cooper ${ }^{27}$ ), Hardwicke resurrected Butts v. Penny and said that trover would lie for a Negro slave: "It is as much property as any other thing." In contrast to Holt's efforts to divorce villeinage and slavery, Hardwicke insisted that the law of the latter grew out of the former.

Unlike his opinion of twenty years earlier, however, Pearne exerted no influence as precedent. It was not presented to the world in a published report until the first edition of Ambler in 1790 (London and Dublin), and even then its weight was problematical given Ambler's poor reputation as a reporter. ${ }^{28}$ Even assuming Hardwicke had actually uttered the words Ambler imputed to him, they were plainly dicta, quite unnecessary to the petition in the bill, which was for a ne exeat regno.

Thirteen years later, in Shanley v. Harvey, ${ }^{29}$ Hardwicke's dicta were emphatically disapproved by his successor in Chancery, Lord

24. The joint opinion is quoted in full in Knight v. Wedderburn, 8 Fac. Dec. 5, Mor. 14545 (Scot. Ct. Sess. 1778).

25. Mansfield interjected during argument in Somerset that the opinion "was upon a petition in Lincoln's Inn Hall, after dinner; probably, therefore, might not, as he believes the contrary is not usual at that hour, be taken with much accuracy." Lofft at 8.

26. Ambl. 75, 27 Eng. Rep. 47 (Ch. 1749).

27. He construed Smith $v$. Brown $\&$ Cooper to be merely a construction of a defective averment, the statement there "pro uno Aethiope vocat. NEGRO" being insufficient to designate the "African" a slave. But Holt, if Salkeld's report is correct, went well beyond that, and not in dicta either.

28. J. Wallace, The Reporters Arranged and Characterized with Incidental REMARKS 513 (4th ed. 1882).

29. 2 Eden 125, 28 Eng. Rep. 844 (Ch. 1762). 
Chancellor Henley (later Earl of Northington). Though Eden's statement of facts does not clarify how the status of the defendant (a black alleged to be a slave of a decedent) became an issue, Henley devoted the whole of his brief opinion to a sweeping declaration in favor of liberty: "As soon as a man sets foot on English ground he is free: a negro may maintain an action against his master for ill usage, and may have a Habeas Corpus if restrained of his liberty." 30 Shanley was no better known than Pearne, because the later and better known of Eden's two editions did not come out until 1827. Even with more publicity, these two Chancery decisions would have had the effect of cancelling each other out: though Hardwicke is esteemed as the greater equity judge, Henley had had the later say.

The highest courts of both common law and equity had spoken on both sides of, and all around, the legal issues of slavery, and their opinions, reported sometimes poorly and always long post hoc, were more a matter of oral tradition than of cold print. The judges and counsel had raised and occasionally canvassed many of the issues presented by the problem of incorporating ownership of man into a legal system which boasted that its greatest glory was being in favorem libertatis; but when Granville Sharp sought to raise, and Lord Mansfield to evade, the problem of slavery in England and the Empire, the issues were far from settled.

\section{II}

By 1770 , some fourteen to fifteen thousand slaves resided in the British Isles. In addition, an unknown number of free blacks lived in the realm, numerous enough to create a special group of London beggars known derisively as "St. Giles' blackbirds." ${ }_{11}$ Most were Africans or Creoles who had been brought to the metropolis, via the island or mainland colonies, as personal servants to West India planters. They had been visible throughout the eighteenth century, and by the 1770s they had attracted the attention of men who had previously been introduced to the antislavery cause through efforts to abolish the British slave trade. Thus crossed

30. Id. at 126, 28 Eng. Rep. at 844.

31. See J. Walvin, Black and White: The Negro and English Society 1555-1945 (1973), for a discussion of Negroes in England before 1770. See generally W. SyPhER, Guinea's Captive Kings: British Anti-Slavery Literature of the XVIIIth Century 2 (1942), on the phrase "St. Giles' blackbirds." See also Walvin, Black Slavery in England, 7 J. Caribbean Hist. 68 (1973). 
the paths of an obscure black, James Somerset, and Granville Sharp, the first great English abolitionist.

Sharp was an unusual person, even in eighteenth century England. A grandson of the Archbishop of York, but son of an impecunious archdeacon, Sharp was self-educated, having been employed first as an apprentice to a cloth merchant and later as a clerk in the Ordnance Department. He resigned the latter post in 1776 because he could not bring himself to make out orders for shipping munitions to the revolting colonies, whose cause he supported. ${ }^{32}$ Sharp was a vigorous pamphleteer, who interested himself in a variety of humanitarian causes and eccentric crusades, but whose darling was antislavery, a cause in which he coupled his talents as propagandist and lay lawyer.

Sharp became involved in antislavery activism in 1767 through some litigation that resulted from his efforts to free a slave named Jonathan Strong. ${ }^{33}$ Strong's master, David Lisle, brought countersuit against Sharp for detainer of the slave. Sharp urged his counsel to defend on the ground that no action could be brought for detainer because the master could not have a property right in a slave, but the attorney rejected this suggestion on the basis of the 1729 Yorke-Talbot opinion. Thus frustrated, Sharp determined to reexamine from scratch questions of slavery, personal liberty, and the right to habeas corpus in England. He was undeterred by the fact that he was a layman with no legal training who wanted to reach a result that had been spurned by two eminent lawyers of the preceding age.

Two years of research produced $A$ Representation of the Injustice ... of Tolerating Slavery, ${ }^{34}$ in which Sharp condemned slavery as a "gross infringement of the common and natural rights of mankind," and as "plainly coutrary [sic] to the laws and constitution of this kingdom" because no laws "countenance[d]" it and others, according to his interpretation, made it actionable. ${ }^{35}$ On this last point, Sharp prepared an essay in statutory construction

32. The beliefs which eventually led to this action are discussed in G. SHARP, A Declaration of the People's natural right to Share in the Legislature; Which is the Fundamental Principle of the British Constitution of State (1774). This constitutional treatise expresses ideas that had many affinities to antislavery theories Sharp was working out at the same time.

33. The story of the Strong litigation is told by Fisher, Granville Sharp and Lord Mansfield, 38 J. Negro Hist. 381 (1943).

34. G. Sharp, A Representation of the Injustice and Dangerous Tendency of Tolerating Slavery; or of Admitting the least Claim of Private Property in the Persons of Men, in ENGLand (1769) [hereinafter cited as Sharp, Representatron].

35. Id. at $40-41$. 
that was the most innovative and suggestive part of the Representation. He drew on a tradition extending back to Magna Charta (1215), which had provided, in its famous 39th chapter, that no freeman ("liber homo") should be killed, imprisoned, or disseised "except by the lawful judgment of his peers or [sc. and] by the law of the land."36 During the reign of Edward III, Parliament had refurbished the per legem terrae provisions by extending Magna Charta's provisions to all men, not just freemen, in a celebrated declaration: "no man of what estate or condition that he be, shall be put out of land or tenement, nor taken nor imprisoned, nor disinherited, nor put to death, without being brought in answer by due process of the law."37 The Habeas Corpus Act ${ }^{38}$ had explicitly extended the protection of the Great Writ to "any person or persons." Sharp argued that these provisions gave all persons in England, including black slaves, a statutory right to contest their restraints in the courts through the writ of habeas corpus.

Here again, procedure was closely tied to substance; for if Sharp's interpretation of the procedural right were to be accepted, the substantive issue of the legality of slavery would be unavoidably raised, if not partially determined. Sharp's view would dissolve the American lawyer's cherished distinction between procedural and substantive due process, for the same claim that would get a slave into court-that he was a protected "person" deprived of his liberty without due process of law-would ipso facto if not ipso jure challenge the very basis of his enslavement. Sharp thus represents a link in the chain of descent from Magna Charta through the medieval Parliaments to the nineteenth century American antislavery movement and the due process clause of the fourteenth amendment.

Having relied on one group of statutes in favor of liberty, Sharp could not avoid another group that recognized or at least condoned slavery: the parliamentary statutes regulating the slave trade, granting concessions to slavers, and confirming masters' property rights in slaves. ${ }^{39}$ In the face of these laws, Sharp simply

36. The translation, including the rendering of vel as meaning both "or" and "and," is from 1 C. Stephenson \& F. Marcham, Sources of English Constitutional History 121 (2d ed. 1972).

37. 28 Edw. 3, c. 3 (1354). See also 20 Edw. 3, c. 4 (1346): "Every Man may be free to sue for and defend his Right in our Courts and elsewhere, according to the Law."

38. 31 Car. 2, c. 2 (1679).

39. See 5 Geo. 2, c. 7 (1732); 23 Geo. 2, c. 31 (I750); 25 Geo. 2, c. 40 (1752). These statutes define "slaves" and "Negroes" as goods, assets, or property. The charter of the New Royal African Company (1672) defined "slaves" and "negroes" as "goods" and "com- 
argued that when statutes create an injustice, courts should treat them as being superseded by statutes favoring liberty, which are of superior obligation. ${ }^{40}$

Although Sharp conceded a contractual basis for slavery-by suggesting, perhaps needlessly, that a man might voluntarily agree, for consideration, to become a slave-he denied that slavery had any other source of legitimacy. This position required him to argue around the imperfectly reported dicta of the previous cases and the Yorke-Talbot opinion. Sharp did what he could with the antislavery precedents, and drew eclectically on continental civil jurists to demonstrate that if questions posed by slavery had to be decided on the basis of property rights, then the right of a slave to the property of his own person and the fruits of his labor overrode any supposed right of the master to either. ${ }^{41}$ "True justice makes no respect of persons," he insisted, "and can never deny to any one that blessing to which all mankind have an undoubted right, their natural liberty." He thus stressed two themes that were to pervade later constitutional antislavery debate: the appeal to natural or higher law to override unjust, merely mundane ordinances, and the idea that a sweeping explicit declaration, such as the all-men-are-born-free-and-equal phrase of the Declaration of Independence, admits of no implicit racial exceptions.

In preparing the Representation and carrying forward the Somerset case, Sharp underwent the vexing frustration of having William Blackstone, already recognized as an authoritative expositor of English law, modify his publicly and privately expressed opinions against the validity of slavery. ${ }^{42}$ In the first edition of his Commentaries on the Law of England, published in 1765, Blackstone had emphatically declared that slavery in its pure form "does not, nay cannot, subsist in England" and had laboriously repudiated three origins of slavery that continental writers had recognized as legitimating it (captivity in war, self-sale, inherited status). Citing Smith

modities". See Calendar of State Papers, Colonial Series, America and West Indies, 1669-1674, at 409-12 (W. Sainsbury ed. 1889). In 1677, Solicitor General Sir Francis Winnington rendered an opinion that "negroes ought to be esteemed goods and commodities within the Acts of Trade and Navigation" requiring commodities exported from English colonies to be shipped in English bottoms. Calendar of State Papers, Colonial Series, America AND West INDies 1677-1680, at 120 (W. Sainsbury \& J. Fortesque eds. 1896).

40. Sharp, Representation at 26-27.

41. Id. at 38; accord, An Argument Against Property in Slaves, 42 Gentleman's Magazine 309-310 (1772).

42. E. Lascelles, Granville Sharp and the Freedom of Slaves in England 22-23 (1928). 
v. Brown and Cooper, Blackstone had ventured the opinion that as soon as a slave comes into England, he becomes free, just the doctrine Sharp was striving for. Blackstone had gone on, though, to suggest that slavery might have a contractual basis, and that whatever rights an English master derived on this basis continued in force and were unaffected by baptism. ${ }^{43}$

Troubled by the uses to which Sharp and others were putting the more libertarian parts of his writings, and not wishing "to pronounce decisively on a matter which is adhuc sub judice," 44 Blackstone cautiously modified the relevant passages in his third edition to remove the implications that slavery rested on a contractual basis and that a slave enjoyed "liberty" under English laws. ${ }^{45} \mathrm{He}$ stated that "whatever service the heathen negro owed to his American master, the same is he bound to render when brought to England and made a christian;" he also revised an earlier statement that a slave becomes free upon coming to England to read that he merely comes under the "protection of the laws, and so far becomes a freeman: though the master's right to his service may possibly still continue." ${ }^{66}$ These were disastrous shifts of emphasis from Sharp's point of view.

Sharp did some research into the colonial statutes concerning slavery, particularly those of Virginia, ${ }^{47}$ but he never came to grips with the critical question they posed for the imperial relationship: how would a decision such as the one sought in Somerset's Case affect the colonies? Could the colonies legitimate slavery in the metropolis by establishing or recognizing it through municipal legislation, as the West India planters contended? Or, conversely, could the metropolitan courts illegitimate it in the colonies by holding it incompatible with the metropolitan constitution? Sharp groped toward the latter possibility in a footnote in the Representation-"wheresoever the bounds of the British empire are ex-

43. 1 W. Blackstone, Commentaries 123, 411-12 (1st ed. 1765).

44. Letter from William Blackstone to Granville Sharp, Feb. 20, 1769. Sharp Trans. NYHS.

45. 1 W. Blackstone, Commentaries 424-25 (3d ed. 1768). One author claims that Blackstone made the change in his second edition. F. SHYLLON, supra note 4 , at 61 .

46. Compare 1 W. Blackstone, Commentaries 123 (1st ed. 1765), with id. at 127 (5th ed. 1773), on this last quoted sentence.

47. Yet he failed to exploit a suggestive passage in Virginia's first comprehensive slave code, Act of 1705 , c. $49, \S 6,3$ Hening 448 (1823), providing that a slave's "being in England" would not work an automatic emancipation without other proof of manumission. Perhaps the statute was an early indication of colonial concern about the issues Sharp was raising. 
tended, there the Common Law of England must of course take place" 48 _but he abandoned the possibility by merely urging that the colonial legislatures have greater respect for the common law principles that underlay the British constitution. He did not explore possibilities implied in the stipulation in colonial charters that the colonial legislatures could enact only laws "not contrary to the laws of this realm of England." 49 This was an avenue that later American antislaverymen exploited.

Whereas the bulk of contemporary abolition agitation in England was directed at outlawing the slave trade or modifying its severities, Sharp's Representation struck directly at slavery itself. The work was, furthermore, an entirely secular effort. This approach was somewhat out of character for Sharp; he was a devout and scrupulously orthodox communicant of the established Church, and spent many of his later years writing pamphlets in defense of orthodox trinitarian doctrine, in striving to convert the Jews, and in proving that the popish church was the Whore of Babylon described in the Book of Revelation. Yet in the Representation he bridled his usual inclinations and stuck to the worldly issues surrounding slavery.

Sharp distributed free copies of the Representation to attorneys to help them propagate the doctrines he had worked out, and simultaneously sought an appropriate case through which to argue his views to a competent court. Several presented themselves between 1770 and 1772, and, according to Thomas Clarkson's recollections, ${ }^{50}$ the black secured liberty in each one; but none of this litigation gave an authoritative answer to the question whether a slave becomes free when brought into England.

But in one of these test cases promoted by Sharp, Mansfield made several tantalizing suggestions about the directions in which the law of slavery might move. In Rex ex rel. Lewis $v$. Stapleton, ${ }^{51}$ the defendant was prosecuted for assault and false imprisonment

48. "[W]hatsoever right the members of a provincial assembly may have to enact byelaws, yet in so doing, they are certainly bound, in duty to their Sovereign, to observe, most strictly, the fundamental principles of the constitution, which his Majesty is sworn to maintain; for wheresoever the bounds of the British empire are extended, there the Common Law of England must of course take place, and cannot be set aside by any private law whatsoever...." ShARp, RePreSENTATION, at 70-71.

49. The wording is from the Connecticut charter (1662), excerpted in 2 C. Stephenson \& F. MARChAM, supra note 36 , at 590.

50. 1 T. Clarkson, The History of the Rise, Progress, and Accomplishment of the Abolition of the African Slave-Trade by the British Parliament $74-75$ (1808).

51. A transcript of arguments and other proceedings in this unreported case is in Sharp Trans. NYHS, from which all quotations in the text are taken. 
for having seized the runaway Lewis for transport and sale outside the realm (the same factual situation involved in Somerset). During the argument, Mansfield stated that being black did not prove that Lewis was a slave; that it was doubtful that the alleged slave "could prove his own Freedom by his own Evidence"; and that whether masters "have this kind of property or not in England never has been solemnly determined." Ultimately Lewis had no precedential value because it turned on the factual question of whether Lewis was actually Stapleton's slave. But in colloquy with John Dunning, counsel for Lewis, Mansfield gave voice to his uneasiness at the prospect of having to pass on the larger legal issues that were at stake: "you will find more in the question then [sic] you see at present. ... It is no matter mooting it now but if you look into it there is more than by accident you are acquainted with. . . . Perhaps it is much better it never should be finally discussed or settled . . . for I would have all Masters think they were Free and all Negroes think they were not because they wo'd both behave better." The "more" that Mansfield so enigmatically mentioned may have been only the value of slave property in England (which, at a conservative valuation, was $\$ 700,000^{52}$ ) or it may have been the legitimacy of slavery itself. Whichever it was, Mansfield was loath to touch the question.

In bringing test cases, Sharp was taking a long gamble. In 1770, it was distinctly possible that English courts would legitimate slavery in England, especially in light of the baneful influence of the Yorke-Talbot opinion and the scattered dicta about trover lying for a Negro. Mansfield, who had already done much to incorporate the law merchant into the common law (thereby creating the foundations of modern commercial law), might recognize property in slaves as a part of "the custom of the merchants" and adapt slavery's features to English law as easily as he had with negotiable instruments. The fact that matters turned out differently, and that Mansfield put human liberty ahead of mercantile greed, should not make us forget Sharp's grounds for pessimism.

\section{III}

James Somerset, according to the return made by the vessel master John Knowles, was born in Africa, brought to Virginia by a slaver in 1749, and bought there by Charles Stewart. Stewart then

52. This estimate, 14,000 slaves at $£ 50$ each, was made by "A West-India Planter." Considerations on the Emancipation of Negroes and on the abolition of the Slave-trade 3 (1788). Mansfield accepted this figure. Lofft at 17. 
moved to Massachusetts, where he was stationed as a customs officer, and from there went to England on business in 1769, taking Somerset along as a personal servant. ${ }^{53}$ In October of 1771 , Somerset fled, but he was recaptured by Stewart, who consigned him to Knowles to be sold in Jamaica. Through the intervention of Sharp and several others, a writ of habeas corpus was secured on Somerset's behalf from Mansfield, who referred the matter for a hearing by the full bench. To represent Somerset and the cause of antislavery, Sharp secured some of the most eminent legal talent of the day: Serjeants William Davy and John Glynn, and barristers James Mansfield ${ }^{54}$ and Francis Hargrave. The last of these, a young man in 1772 , made his reputation with his arguments in this case.

On the other side, representing Stewart, the West India Interest, ${ }^{55}$ and the cause of slavery, were the equally eminent barristers John Dunning, who had represented the slave Lewis the previous year, and William Wallace. Apparently neither Dunning nor his nominal client relished their roles as cat's-paws for the West India Interest. Stewart wrote in 1772 that "the West India planters and merchants have taken [the case] off my hands; and I shall be entirely directed by them in the further defence of [the case]." 56 At the same time Dunning noted at the beginning of his oral argument that he had the "misfortune to address an audience, the greater part of which, I fear, are prejudiced the other way." 57

Mansfield deferred decision for a year, and ordered a total of five separate hearings. He repeatedly urged Stewart to moot the matter by voluntarily liberating Somerset, but Stewart refused, causing Mansfield to remark plaintively and in exasperation after the last argument, "If the parties will have judgment, 'fiat justitia, ruat coelum' ['let justice be done though the heavens fall']." There was a nettlesome policy consideration that had been aired repeatedly in the public papers and arguments of counsel on both sides of the question: delegitimation of slavery (which all assumed would discourage the further importation of slaves) would exclude from England not only the abstract legal relationship, but

53. Washburn, Somerset's Case, and the Extinction of Villenage and Slavery in England, [1863-1864] Proceedings of Mass. Hist. Soc. 307, 323 (1864).

54. No relation to Lord Mansfield.

55. The West India Interest was a combination of planters resident in the colonies and the metropolis, together with the merchants trading in the islands, and their agents, attorneys, and spokesmen in the metropolis. See E. Williams, Capiralism \& Slavery (1944).

56. Washburn, supra note $\mathbf{5 3}$, at 324 .

57. Lofft at 9-10. 
also the black men and women who were its victims. The exclusion of blacks would "preserve the beauty and fair complexion of our people, which otherwise is in a probable way of becoming Morisco, like the Spaniards and Portuguese"58 — which, as Serjeant Davy warned in his argument for Somerset, "would occasion a great deal of Heart Burn." 59

Whatever Mansfield's feelings in the matter may have been, he had little room to maneuver because of the pertinacity of Sharp and the West India Interest, both of whom saw the suit as a climacteric test case. Both tried to move the decision along by publishing legal arguments in the matter. Hargrave published his arguments before the court as An Argument in the Case of James Sommersett a Negro .... ${ }^{60}$ The Argument, a carefully drawn lawyer's brief, adopted the line of reasoning suggested by Sharp: first, the laws of England had never countenanced slavery, except in the institution of villeinage, which by 1770 had been defunct for well over a century; second, slavery was antithetical to other parts of the English laws and constitution. The law of contracts would not permit an individual to enslave for life both himself and his posterity, nor permit him to subject himself to other incidents of slavery, such as salability. Thus, Hargrave summarized, if English law would not tolerate slavery by consent, much less could it permit slavery that had its origin in oppression.

Hargrave then turned to the question of the imperial relation and slavery. He argued that the statutes protecting the Royal African Company, even if construed most favorably to the interests of the slaveholders, permitted slavery to be introduced only into the colonies, not into the metropolis. Conceding its legitimacy in the colonies for the sake of argument, Hargrave denied that the lex loci of the slave colonies could exert any force in the metropolis, given the impolicy of introducing slavery into England. Hargrave's effort, while thorough, was pedestrian and of limited utility for those who would attack slavery in the colonies. He had set his sights low, hoping to show only that England tolerated no form of slavery but villeinage, by then extinct.

To counter Sharp and Hargrave, the West India Interest procured publication of several pamphlets defending the legitimacy

58. Some observations upon the slavery of Negroes, 34 Scots MAG. 299, 301 (1772).

59. This is from the transcript of Davy's argument in Sharp Trans. NYHS.

60. F. Hargrave, An Argument in the Case of James Sommersetr a Negro Lately Determined by the Court of King's Bench: Wherein IT IS ATteMpted to DEMONSTRATE the Present Unlanfulness of Domestic Slavery in England. To which is prefixed a State of the Case (1772). 
of slavery in England. They appealed most forcefully to Mansfield in Samuel Estwick's Considerations on the Negroe Cause . . . . ${ }^{61}$ Relying heavily on the 1729 Yorke-Talbot opinion, Estwick insisted that Parliament, in the Royal African Company statutes, had recognized a legitimate property relationship in slaves. ${ }^{62}$ Even though this was a form of property "established by power and maintained by force," it was legitimate both in the metropolis and in the colonies. He emphasized that since the colonial laws had to conform to the laws of England, slavery had to be a valid institution in England; else it would have been void under the conformity requirement. Circular as this reasoning was, it was responsive to the imperial relationship question and, if it had been accepted, might have validated slavery under the British constitution.

Thomas Thompson, another proslavery pamphleteer, defended the slave trade against Sharp's-natural law arguments by admitting that all persons are free under natural law. "But absolute freedom is incompatible with civil establishments. Every man's liberty is restricted by national laws and natural priviledge [sic] does rightly yield to legal constitutions ...."63 The English constitution incorporated slavery, Thompson concluded, on the captivity-in-war-rationale.

In the oral arguments, Davy and Glynn opened on February 7, 1772 (Hilary term). Mansfield ordered the case held over till Easter term, when Mr. Mansfield, Hargrave, and Alleyne concluded arguments on the slave's side. According to the notes of the reporter of the decision, Capel Lofft, Hargrave's oral argument was broader in scope than his pamphlet argument; he insisted that "freedom is the grand object of the laws" in England, overriding inconsistent laws of the plantations and foreign nations. English courts could recognize slavery only extraterritorially, therefore, under the sanction of local laws in the colonies, and not under the laws of England. Alleyne elaborated on this point: "But slavery is not a natural, 'tis a municipal relation; an institution therefore confined to certain places, and necessarily dropt by passage into a country where such municipal regulations do not subsist." Though this went a good deal further than Mansfield

61. S. Estwick, Considerations on the Negroe Cause Commonly so Called, Addressed to the Right Honourable Lord Mansfield, Lord Chief Justice of the Court of King's Bench, ETc. (1772).

62. Accord, Considerations on a late Determination in the Court of King's Bench on the Negroe Cause, 42 Gentleman's Mag. 307-08 (1772).

63. T. Thompson, The african Trade for Negro Slaves, Shewn to be Consistent with Principles of Humanity, and with the Laws of Revealed Religion 23 (1772?). 
was prepared to go, Alleyne's insistence that slavery was not a "natural" relation, that is, one consonant with natural law, was compelling, and was to be adopted by Mansfield as the heart of his opinion.

Wallace, counsel for the West India Interest, took a different tack and insisted that slavery could exist in England simply because no law forbade it. He was followed by Dunning, who, according to Lofft's recollection, relied chiefly on an argumentum ad horrendum: liberate the slaves in England, and Jamaica's 160,000 blacks will come to England, or rise in insurrection against their masters. He argued that slavery was a form of property relationship, recognized as such in England.

\section{IV}

As Easter term 1772 wore on, it must have become apparent to Mansfield that he could not evade the dilemma thrust on him by Sharp and Hargrave on one hand, and the West India Interest on the other. Serjeant Davy in argument bluntly stated the first horn of the dilemma: "If the Laws having attached upon him abroad are at all to affect him here it brings them all, either all the Laws of Virginia are to attach upon him here or none-for where will they draw the Line?"64 Mansfield agreed: "[T]he difficulty of adopting the relation, without adopting it in all its consequences, is indeed extreme; and yet, many of those consequences are absolutely contrary to the municipal law of England."65 $\mathrm{He}$ did not want to see the colonial tail wag the metropolitan dog by incorporating slavery into the English legal order.

On the other hand, he continued, "the setting 14,000 or 15,000 men at once free loose by a solemn opinion, is much disagreeable in the effects it threatens." Not only would this racially alien mass of humanity be set free of their masters' discipline and support; the masters' property rights would be shaken-no light matter to a conservative jurist like Mansfield. Furthermore, the law would be unsettled: " $[\mathrm{H}]$ ow would the law stand with respect to their settlement? their wages? How many actions for any slight coercion by the master?"

In rendering the decision Mansfield settled on a dual strategy to dispose of the unwelcome case. First, he reaffirmed one point

64. This is from the transcript of Davy's argument in Sharp Trans. NYHS.

65. Lofft at 17. An argument somewhat analogous to this one on the incompatibility of slave discipline with English law was hinted at in an untitled note in 34 GentLeman's MAG. 493 (1764). 
of English law that he thought was well settled-c"contract for sale of a slave is good here; the sale is a matter to which the law properly and readily attaches"-and hinted that the West India Interest should resort to Parliament (where they had considerable influence as well as a few members) to have other points of the law resolved by statute. ${ }^{66}$ Second, he reduced the issue before him to the narrowest possible scope-the only question was whether any "coercion can be exercised in this country, on a slave according to the American laws?" Furthermore, this question was to be determined solely on the basis of the pleadings (that is, whether the return to the writ was sufficient). ${ }^{67}$

Yet the impact Mansfield so earnestly sought to restrict became uncontrollable as soon as he tried to explain the result he had reached, which was to discharge Somerset on the writ. He spoke to two points, one relating to conflict of laws, and the other to the opposition between natural and municipal law; and on both points, his utterances gave Somerset its lasting and reverberating influence.

On the conflicts question, Mansfield asserted that "so high an act of dominion [seizing a slave for sale abroad] must be recognized by the law of the country where it is used. The power of a master over his slave has been extremely different, in different countries." This statement laid down a general rule that the lex domicilii by which a person is held in slavery does not of its own force determine the slave's status in England, even though the lex fori and the lex domicilii are based on the same general corpus of statutory and common law, as was true of the metropolis and the colonies in the British empire. ${ }^{68}$

Manśfield's statement on natural and municipal law had an even greater impact.

The state of slavery is of such a nature, that it is incapable of being introduced on any reasons, moral or political; but only

66. The planters did have a bill introduced in Parliament to legitimate the slave relation in England. Letter from Alleyne to Granville Sharp, Jan. 13, 1773, Sharp Trans. NYHS. Nothing came of it. See Fiddes, supra note 7, at 503.

67. According to a newspaper account in The Gazetter, May 26, 1772, quoted in F. Shyllon, supra note 4, at 115, Mansfield had earlier framed the issue thus: "the only question properly before us is, whether the colony slave-laws be binding here, or if there be established usage or positive law in this country that sufficiently countenances the coercion here contended for."

68. So decisive was this determination that when Justice Joseph Story composed his magisterial Commentaries on the Conflict of Laws in 1834, he based a major portion of his argument against the "ubiquity" status of leges domicilii on the Somerset principle. J. STORY, Commentaries on the Conflict of Laws \$\$ 95-96a (2d ed. 1841). Story's position, in turn, complicated the workings of the American federal system. 
positive law, which preserves its force long after the reasons, occasion, and time itself from whence it was created, is erased from memory: It's so odious, that nothing can be suffered to support it but positive law. ${ }^{69}$

These forceful assertions raised more questions than they answered. Did "positive law" include custom? Did it require that the legislative or executive authority actually establish slavery, rather than merely recognize its existence in slave codes? If slavery was contrary to natural law, could even positive law establish it? ${ }^{70}$

To the extent that Mansfield implicitly relied on natural law to establish the "odious" character of slavery, he seemed curiously out of step with contemporary legal developments. According to J. W. Gough, ${ }^{71}$ the heyday of fundamental or natural law had apparently passed in England a century before Somerset, though it has persisted in the United States into our own times. Yet Mansfield's application of natural law may not have been as anachronistic as it seems. The conception of fundamental law that concerned Gough was that of a limitation on the power of Parliament, and that notion surely was passé in eighteenth century English constitutional thought. But natural law could also serve as a standard of justice against which exogenous institutions might be tested to determine their suitability for incorporation into English law. And that was precisely the use to which Mansfield put it. In this sense, natural law was not yet obsolete in English thought, though it lacked the force it was later to have in American constitutionalism.

Mansfield concluded his brief opinion on a note of "I-told-youso" to the planters: "Whatever inconveniences, therefore, may follow from a decision, I cannot say this case is allowed or approved by the law of England; and therefore the black must be discharged."

Despite the sweep and implications of its language, this opinion did not abolish slavery even in England itself, as Mansfield and others $^{72}$ were later at pains to point out. Somerset notwithstanding,

69. Lofft at 19.

70. In this portion of his opinion, Mansfield's position was strikingly similar to provisions of the Cuban Slave Code, which derived ultimately from the Institutes of Justinian and which was influenced by the Siete Partidas (1265). The Partidas stated that slavery was contra razon de natura, and the Cuban code, in its introduction, declared slavery to be "the most evil and the most despicable thing which can be found among men." H. KLEIN, Slavery in the Americas: A Comparative Study of Virginia and Cuba 59 (1967).

71. J. Gough, Fundamental Law in ENGlish Constitutional History 174 (1955).

72. See, e.g., D. Barrington, Observations on the More Ancient Statutes From Magna Charta of the Twenty-first of James I Cap. XXVII. . . . at 312 (1775). 
a qualified form of slavery continued to exist in England until final emancipation in $1833 .^{73}$ Far from abolishing slavery in toto, Mansfield had held merely that, whatever else the master might do about or with his claimed slave, he could not forcibly send him out of the realm, and that habeas corpus was available to the black to forestall the threatened deportation.

Masters soon learned to evade even this narrow holding of Somerset, exploiting Mansfield's hint that the master-slave relationship could persist on the basis of the lex loci contractus rather than the lex loci domicilii. Masters in the colonial jurisdictions who wished to take a slave temporarily to England could simply force him to sign or mark an indenture, under which he could be held while in England as an indentured "servant" and, presumably, forced to return, nolens volens, to the colonies, where his slave status would reattach. ${ }^{74}$

Despite the restricted scope of the holding, and the later efforts of Mansfield and others to clarify the case and foreclose its more liberating possibilities, Somerset burst the confines of Mansfield's judgment. This expansion occurred chiefly for two reasons. First, the judgment itself, discharging a black alleged to be a slave on a writ of habeas corpus, struck a more profound blow at slavery than the hasty and superficial opinion of Benjamin Franklin recognized. ${ }^{75}$ The very fact that habeas corpus would allow a black to test the legitimacy of his putative master's claim to him was a great extension of the Great Writ and a threat to the security of slavery in England. Second, Mansfield's statements justifying the result, as reported by Capel Lofft, had implications that Mansfield probably did not foresee and that the defenders of slavery would have cause to regret.

English courts began almost immediately to wrestle with the ambiguities and potentialities of Mansfield's opinion. Some English judges assumed that Somerset had accomplished the complete abolition of slavery in England. In an unreported case, Cay $v$. Crichton, ${ }^{76}$ decided in 1773 , the year after Somerset, the presiding judge held that the determination had retroactive effect, so that slavery had never had a legitimate existence in England, at least

73. F. Shyllon, supra note 4, at chs. x-xiii; M. Thomson, A Constrtutional History of ENGLAND 1642 to 1801 , at 420 (1938). For a general discussion of the status of blacks in Britain after Somerset see J. WALviN, supra note 31 , at chs. viii-xiii.

74. J. WALvin, supra note 31 , at 135 .

75. See text and note at note 6 supra.

76. (Prerog. Ct. 1773). The decision in this case appears in the Sharp Trans. NYHS. 
for purposes of including an alleged slave in a decedent's inventory. A Scottish case heard before the Court of Sessions, Knight $v$. Wedderburn, ${ }^{77}$ further suggested that the impact of Somerset would be extensive. Counsel for a runaway slave claimed his client's freedom on the ground that slavery could not be upheld under Scottish law, and he cited Somerset only for its narrow and technically correct holding. But the court, without explicitly citing the case, held that the master's dominion over his slave, in reliance on the law of Jamaica, was "unjust" in Scotland and of no obligation. Not only could the master not send his slave out of the country; he had no right to exact services from him in Scotland either.

Vexed by such interpretations, ${ }^{78}$ Mansfield seized an opportunity in Rex $v$. Inhabitants of Thames Ditton ${ }^{79}$ to lecture the English bar on the precise limits of the Somerset opinion. Though Thames Ditton turned on a question of statutory interpretation that did not necessarily involve the legitimacy of slavery in England, Mansfield engaged in some revealing dialogue with counsel. The action was to determine whether a parish was responsible for the support of a pauper under the poor laws; the pauper was a black who had been brought to England as a slave. In the course of an involved argument concerning interpretation of the poor laws, counsel suggested that King's Bench had never decided that a slave brought into England was bound to serve his master. Mansfield interjected reprovingly: "the determination got no further than that the master cannot by force compel him to go out of the kingdom"- a precise construction of the holding of Somerset. Counsel tried again, suggesting that the slave relationship imimplies a hiring, and again Mansfield cut short that line of argument: "The case of Somerset is the only one on this subject. Where slaves have been brought here, and have commenced actions for their wages, I have always non-suited the plaintiff."

The explicit doctrine of the Scottish courts notwithstanding, all but one part of the Yorke-Talbot opinion remained intact in England. The scope of habeas corpus for slaves and other unfree persons remained largely undefined, and the incompatibility of

77. 8 Fac. Dec. 5, Mor. 14545 (Scot. Ct. Sess. 1778).

78. Ex-Governor Thomas Hutchinson, the American loyalist, recalled that Mansfield remarked to him in conversation on August 29, 1779, "that there had been no determination that they were free, the judgment (meaning the case of Somerset) went no further than to determine the Master had no right to compel the slave to go into a foreign country, \&:c." 2 The Diary and Letters of His Excellency Thomas Hutchinson, EsQ. 277 (P.O. Hutchinson ed. 1886).

79. 4 Doug. 300, 99 Eng. Rep. 891 (K.B. 1785). 
earlier precedent was unresolved. ${ }^{80}$ Yet loose aphorisms about slaves being liberated once they set foot on English ground remained unchecked and hence potent. Somerset fired the imagination of the poet William Cowper, who wrote exultantly but altogether inaccurately:

Slaves cannot breathe in England, if their lungs

Receive our air, that moment they are free

They touch our country, and their shackles fall. ${ }^{81}$

Moreover, despite Mansfield's later construction, broad readings of Somerset persisted in the courts. Justices in both the Court of Common Pleas and King's Bench read it to mean that a black slave, at least while in England, was, in the words of Lord Chief Justice Alvanley, "as free as any one of us." 82 In Forbes v. Cochrane $\mathcal{E}^{2}$ Cockburn, ${ }^{83}$ an 1824 King's Bench case, Justice Holroyd found slavery to be a "law in invitum," so that a slave escaping into free territory thereby liberated himself from any claim the master might have upon him. He went so far as to say that when a slave "puts his foot on the shores of this country, his slavery is at an end" simply because no municipal law of England sanctioned slavery. His colleague, Justice Best, went further, construing Somerset to have held "on the high ground of natural right" that slavery was "inconsistent with the genius of the English constitution," and that human beings could not be the subject matter of property. To be sure, Lord Chancellor Eldon took a different view during abolition debates in the House of Lords, maintaining that it was most unlikely that slavery was "contrary to the genius of the British constitution" in view of the Royal African Company statutes. ${ }^{84}$ Yet William Holdsworth, premier historian of English law, considered Best's interpretation not only the "popular view," but also "substantially correct." 85

80. A Letter to Philo Africanus, Upon Slavery . . . with the Sentence of Lord Mansfield, In the CaSe of Somerset and Knowles, 1772, with His LoRdship's ExPLANATION OF THAT OPINION IN 1786 (1788).

81. From "The Task," a poem in 2 The Poetical Works of William Cowper 147 (H. Milford ed. 1926). Edward Christian, one of Blackstone's early editors, observed more accurately that "it is not to the soil or to the air of England that negroes are indebted for their liberty, but to the efficacy of the writ of habeas corpus. . ." W. BLACESTONE, Commentaries 127, editor's note (E. Christian ed. 1822).

82. Williams v. Brown, 3 Bos. \& P. 69, 71, 127 Eng. Rep. 39, 41 (C.P. 1802).

83. 2 Barn \& Cres. 448,107 Eng. Rep. 450 (K.B. 1824).

84. 14 PARL. Deb., H.L. (2d ser.) 1156 (1826).

85. 11 W. Holdsworth, A History of English Law 247 n.l (1938). 
Conservative jurists who felt a need to ground interpretive flights like Best's were cheered by an opinion from Lord Stowell, who presided over the High Court of Admiralty. This decision, known variously as The Slave Grace or as Rex $v$. Allan, ${ }^{86}$ was considered by some contemporaries, including so eminent an authority as Justice Joseph Story of the United States Supreme Court, ${ }^{87}$ to be the definitive interpretation of Somerset. But these authorities exaggerated the influence of the case. It was actually an effort by an elderly and conservative admiralty judge, who did not have the power to modify a decision of King's Bench in any way, to redirect and restrict the implications of Mansfield's words. The effort proved to be fruitless in America.

The circumstances of Grace's case were almost perfect for a test of the implications of Somerset. The slave had been brought by her mistress from Antigua to England, where they resided for a year. They then went back to Antigua, where the slave was seized by admiralty officials as illegally imported. The officials' assumption was that she had become free in England and thus was a free person being brought into slavery. Stowell affirmed a judgment for the mistress, on the ground that the slave, on her return to Antigua, reassumed her status as a slave, which had only been suspended, not terminated, during her stay in England.

Most of Stowell's long and elaborate opinion was an effort to prune the luxuriant growth of antislavery interpretation stimulated by Somerset. He insisted that slavery had a legitimate origin in "ancient custom," which was "generally recognized as a just foundation of all law." Though it did not exist in England, slavery did have a legal existence in the colonies; it was incompatible only with English law, and even in England the incompatibility extended no further than to confer on the slave a "sort of limited liberty" that evaporated upon his return to a slave jurisdiction. Stowell expressed this idea in a striking metaphor: for slaves coming into the realm, English laws "put their liberty, as it were, into a sort of parenthesis."

Shortly thereafter, in the Abolition Act of 1833, ${ }^{88}$ Parliament removed the supposed parentheses and granted liberty to the slaves in the colonies. Colonial emancipation provoked considerable constitutional debate, but in the end few doubted Parlia-

86. 2 Hagg. 94, 166 Eng. Rep. 179 (Adm. 1827).

87. Letter from Joseph Story to Lord Stowell, Sept. 22, 1828, reprinted in 1 LIFE AND LetTers of Joseph STORY 558 (W. Story ed. 1851). See also J. Story, supra note 68, § 96 a. 88. 3 \& 4 Will. 4 , c. 73. 
ment's power to bind the colonies. That theoretical consensus was a considerable advance over the intellectual climate of sixty years earlier. But what was settled in 1833 had still been inchoate in 1772; before the American Revolution, one of the most unsettling implications of Mansfield's opinion had been the suspicion that slavery, being incompatible with the English constitution, might be illegitimate in the colonies as well. The Americans' struggles with that reasoning will be canvassed next.

\section{V}

Before 1776, the English constitution could not adequately structure the relations between Britain and an individual mainland colony; nor could the individual colony constitutions do so. To understand the workings of the imperial federation, let us assume that these two constitutional systems interacted in a way that produced a relationship we can denominate the "imperial constitution," a set of arrangements more inchoate, more fluid than either of the recognized constitutions. ${ }^{89}$ For a relationship that in 1772 was itself hazy and unsettled, Somerset was a troublesome diversion that raised portentous questions. If, as some inferred from Mansfield's language, slavery was incompatible with the English constitution, what was its status in the English colonies? Did the common law exist there in full force, and, if so, was slavery equally out of place there? What effect should be given to colonial statutes that, if enacted by Parliament for England, would be in derogation of the common law? Did a colonial statute or custom recognizing slavery acquire any greater validity by the enactment of parliamentary statutes encouraging the slave trade or creating the Royal African Company? In Somerset, Mansfield had only begun to treat issues arising under the English constitution; he did not even arrive at the threshold of imperial constitutional problems.

With the advantage of two hundred years' hindsight, we can see the problem in a clearer outline than was possible for Mansfield and Sharp. It is certain that the eighteenth century imperial constitution would have permitted the Privy Council to disallow colonial statutes contrary to the common law. Furthermore, several attorneys general (including Mansfield himself, before his

89. The notion of an imperial constitution may be debatable. But if we view a constitution as the set of written and unwritten principles that guide the workings of any polity's government, then by definition the British empire had a constitution. See generally A.B. Keith, Constitutional History of the First British Empire 165 passim (1930). 
elevation to the peerage, when he was simply William Murray, K. C.) had rendered opinions casting doubt on the binding effect of colonial laws repugnant to the principles of the English common law. ${ }^{90}$ By the middle of the nineteenth century, things had changed considerably; the new order was recognized by the Colonial Laws Validity Act of $1865,{ }^{91}$ which provided that no colonial law should be deemed repugnant to the laws of England unless it was in explicit conflict with an act of Parliament or an order or regulation having the effect of an act of Parliament. Thus, antislavery theorists of the 1840 s who argued that slavery, because of its repugnance to the common law, never had a legitimate origin in America (and hence had no legal existence subsequently) were thinking anachronistically by almost a century; but if Sharp or Hargrave had made the same argument, it might have had some force.

This is not to say that colonial black laws were void in the eighteenth century; that problem had still not been reached, much less worked out, when the American Revolution mooted the question for the mainland colonies. Had the issue been forced to a decision, it is unlikely that Parliament, the Privy Council, or any of the courts would have illegitimated slavery by a simple assertion that colonial statutes in derogation of the common law were void. Some statutes probably would have been voided, but which ones would have depended on a variety of considerations, such as whose ox was being gored. Supporters of the colonial black laws had little to fear from the defenders of the common law, given the political pull of the West India Interest in Parliament, and the Crown's substantial interest in the well-being of the navy, which until around 1790 was a mainstay of the slave system. ${ }^{92}$

The decision and the arguments in Somerset became known almost immediately in the mainland colonies. Extracts from

90. See the opinions of William Murray (1755), Yorke \& Talbot (1730), and Barbados Attorney General Rawlin (1717), reprinted in G. Chalmers, Opinions of Eminent Lawyers on Various Points of English Jurisprudence, Chiefly Concerning the Colonies, Fisheries, and Commerce of Great Britain 341, 333, 373 (1858). General discussions on this subject are found in 11 W. Holdsworth, supra note 85, at 56, and in A.B. KeITH, supra note 89 , at $182-86$.

91. 28 \& 29 Vict., c. 63.

92. Some idea of the direction and content of this hypothetical debate can be derived from the actual discussions that took place between West Indian assemblies and the metropolitan government during the controversy over emancipation in the $1820 \mathrm{~s}$ and $1830 \mathrm{~s}$. The constitutional arguments of this debate are summarized in R. Schuyler, Parliament and the British Empire: Some Constitutional Controversies Concerning Imperial LEGISLATIVE JURISDICTION 117-193 (1929). 
Sharp's Representation and Hargrave's Argument were reprinted in Philadelphia and Boston in 1773 and 1774 respectively. Of course, they did not fall on an American mind that was tabula rasa where antislavery ideas were concerned. Rather, they were just one added element in a ferment of antislavery activity in the northern colonies. Judge Samuel Sewall had attacked slavery in the Bay colony as early as 1700 in his tract The Selling of Joseph. ${ }^{93}$ Quakers in the middle colonies, including John Hepburn, Elihu Coleman, Ralph Sandiford, Benjamin Lay, John Woolman, and Anthony Benezet, had borne witness against slavery, agitated against it among Friends, and published the bulk of the pre-Revolution antislavery tracts. James Otis denounced slavery twice shortly before the beginning of the Revolution, first in his argument in the Writs of Assistance Cases $(1761)^{94}$ and then at greater length in The Rights of the British Colonies Asserted and Proved, ${ }^{95}$ where he insisted that all Americans, "white or black", "are by the law of nature freeborn." Otis's efforts were followed by an outpouring of antislavery agitation from Boston that scored white Americans for their efforts to overthrow the comparatively mild form of "slavery" imposed on them by Britain, while forcing the real thing on their black fellow-countrymen. ${ }^{96}$ These activists were supported by the New England clergy, who preached Biblical antislavery messages to congregations in Boston, Newburyport, and Hartford. ${ }^{97}$ So widespread was antislavery sentiment in the Boston area that the topic assigned for the formal debate at the Harvard College commencement exercises in 1773 was whether slavery was "agreable [sic] to the law of nature" even though sanctioned by

93. S. Sewall, The Selling of Joseph: A Memorial (1700).

94. See 10 Works of John Adams 314-16 (C.F. Adams ed. 1856). This is a letter from John Adams to William Tudor, June 1, 1818, which includes Adams' recollection of the speech.

95. See 1 Pamphlets of the American Revolution 1750-1776, at 408 (B. Bailyn ed. 1965). This particular pamphlet was printed in 1764.

96. See J. Allen, An Oration on the Beauties of Liberty; or the Essential Right of the Americans (1773); J. Allen, The Watchman's Alarm to Lord N-h (1774); The Appendix: or, Some Observations on the Expediency of the Petition of the Africans, living in Boston, \&c. (1773) [hereinafter cited as The Appendix]; N. Appleton, Considerations on SLavery. In a LetTer to a Friend (1767); B. Rush, A Vindication of the Address, to the Inhabitants of the British Settlements, on the Slavery of the Negroes in America 30 (Philadelphia ed.) (1773); J. Swan, A Dissuasion to Great Britain and the Colonies from the Slave Trade to Africa. Shewing the Injustice THEREOF, \&C. (1773).

97. S. Cooke, A Sermon Preached at Cambridge, in the Audience of His Honor Thomas Hutchinson Ese. (1770); J. Edwards, The Injustice and Impolicy of the Slave Trade, and the Slavery of Africans 27 (2d ed. 1822); L. Hart, Liberty DeSCRIBEd ANd Recommended; in a Sermon (1775); N. Niles, Two Discourses on Liberty; 
positive law. ${ }^{98}$ The same subject had been canvassed earlier (1768) in a commencement debate at the College of Philadelphia (the predecessor of the University of Pennsylvania). ${ }^{99}$

The impact of Somerset in the colonies, and particularly in Massachusetts, took various forms. Some of the most revealing reactions came from blacks. Whether enslaved or free, blacks were not indifferent to the rhetoric of liberty they heard about them daily. As a group of black slaves in Massachusetts wrote, possibly through a white amanuensis, in a petition to the General Court, "the efforts made by the Legislature of the province in their last sessions to free themselves from Slavery, gave us, who are in that deplorable state, a high degree of satisfaction." 100 Thus attentive to the whites' notions of liberty, blacks hearing of Somerset brought suit in the Massachusetts courts against their masters, seeking not only freedom but also recovery on quantum meruit. ${ }^{101}$ In these freedom suits, the blacks contended that they could not be enslaved because there was no positive law permitting anyone to hold a human in slavery, and that slavery was contrary to the common law. ${ }^{102}$ These suits, according to a contemporary account, were uniformly successful. ${ }^{103}$ The oral tradition of these arguments and suits later led Lemuel Shaw, antebellum Chief Justice of the Massachusetts Supreme Judicial Court, to speculate that Somerset, of its own force, may have abolished slavery in Massachusetts. ${ }^{104}$ In this opinion he was clearly wrong, as the historian of Massachusetts slavery, George Moore, maintained a century ago: "[T]he institution of slavery continued to be recognized by law in Massachusetts, defying all direct attempts to destroy it." 105

White friends of slaves made still different uses of Somerset. Doctor Benjamin Rush in 1773 proposed the relatively moderate

Delivered at the North Church, in Newbury-port (1774); S. Webster, A Sermon Preached Before the Honorable Council (1777).

98. See T. Parsons \& F. Pearson, A Forensic Dispute on the legality of Enstaning the Africans, Held at the Public Commencement in Cambridge (1773).

99. 2 Pennsylvania Chronicle and Universal Advertiser, Dec. 5, 1768, at 394.

100. Reprinted in J. Allen, AN Oration, supra note 97.

101. Belknap, Queries Respecting the Slavery and Emancipation of Negroes in Massachusetts, Proposed by the Hon. Judge Tucker of Virginia, and Ansuered by the Rev. Dr. Belknap, 4 CollecTIONS OF THE Mass. Hist. Soc., 1st ser., 191, 202 (1795).

102. Letter from E.A. Holyoke to Jeremy Belknap, quoted in Belknap, Letters and Documents Relating to Slavery in Massachusetts, 3 Collections of THE Mass. Hist. Soc. 5th ser., 374, 400 (1877) [hereinafter cited as Belknap, Letters].

103. Id. at 386, quoting a letter from Samuel Dexter to Jeremy Belknap, Feb. 23, 1795.

104. Commonwealth v. Aves, 35 Mass. (18 Pick.) 193, 209 (1836).

105. G.H. Moore, Notes on the History of SLAvery in Massachusetrs 124 (1866). Other slaves acted on their interpretation of Somerset differently. Gabriel Jones, a Virginian, 
course of petitioning the King to disband that "incorporated band of robbers," the Royal African Company, because "we have more reason to expect relief from (such) an application at this juncture, as, by a late decision in favor of a Virginia slave at Westminster-Hall, the Clamors of the whole nation are raised against [the African slavers]". ${ }^{106}$

The most extreme use of Somerset was made in 1773 by an anonymous American editor of Granville Sharp's Essay on Slavery. ${ }^{107}$ Reading Somerset to have held that "slavery is not consistent with the English constitution, nor admissable [sic] in Great-Britain," the editor asked why it should be "continued" in the colonies. Since slavery, even as tolerated by Parliamentary legislation, might be void for inconsistency with "natural rights" or "natural liberty," and since American settlers had brought with them all the "rights, liberties, and privileges" of the British constitution, "why is it that the poor sooty African meets with so different a measure of justice in England and America, as to be adjudged free in the one, and in the other held in the most abject Slavery?" Making a remarkable leap that linked the Sharp-Mansfield doctrines with the problem of the imperial constitution, the editor declared that the colonists were forbidden to make laws inconsistent with the laws of England. Because slavery is inconsistent with "the principles of the [English] constitution, neither in England or any of the Colonies, is there one law directly in favour of, or enacting Slavery, but by a kind of side-wind, ${ }^{[108]}$ admitting its existence, (though only founded on a barbarous custom, originated by foreigners) attempt its regulation" [sic]. Then, forsaking this advanced position, the author concluded rather lamely that he hoped the principles of Somerset would be received in the colonial courts.

advertised for his runaway slave Bacchus in 1774, advising potential captors that Bacchus might try "to get on Board some vessel bound for Great Britain, from the Knowledge he has of the late Determination of Somerset's Case." Virginia Gazette, June 30, 1774, at 3, col. 1 (Purdie \& Dixon ed.).

106. B. Rush, An Address to the Inhabitants of the British Settlements in AMERICA, UPON SLAVE-KEEPING 21-22 (1773).

107. G. Sharp, An Essay on Slavery, Proving from Scripture Its Inconsistency with HUManity and Religion (1773). The edition was published by Isaac Collins of Burlington, New Jersey. Thomas E. Drake attributes the introduction, from which quotations in text are taken, to Samuel Allinson. T. Drake, Quakers and Slavery in America 222 (1950). Joseph Smith attributes it to Allinson and William Dillwyn jointly. 1 J. SMITH, A Descriptive Catalogue of Friends' Books 533 (1867).

108. That is, "[a]n indirect means, method, or manner." Oxford ENGLISH Dictionary (1933). 
This New Jersey Quaker was seconded by pamphleteers and lawyers in Massachusetts, who attempted to show that slavery, or at least the slave trade, was "repugnant to the Charter of this Province, which must be deemed the great Bulwark and Support of our Liberty." 109 The charter provision referred to (in the Massachusetts royal charter of 1691 , which in this respect repeated phraseology found in the other colonial charters) provided that all American migrants or natives "shall have and enjoy all Liberties and Immunities of free and natural subjects within any of the Dominions of Us . . . as if they ... were born within this Our Realm of England." An anonymous correspondent in the Boston Massachusetts Spy asserted that this provision, of its own force, nullified all provincial slave laws. ${ }^{110}$ In contemporary freedom suits, this argument was amplified to include the claim that, under English law, "no man could be deprived of his liberty but by the judgment of his peers." 111

Even before the Declaration of Independence, therefore, two persistent strains of later antislavery argument had been articulated: the appeal to the privileges and immunities of Americans, and resort to natural law concepts incorporated into constitutional due process guarantees. When linked with Somerset, these principles were thought by some contemporaries to accomplish a positive emancipation of every slave setting foot on American colonial territory. This point was suggested by the Philadelphian Richard Wells, who contended that "by the laws of the English constitution, and by our own declaration, the instant a Negro sets his foot in America, he is as free as if he had landed in England."112

Sharp and other English antislaverymen, such as Thomas Clarkson, ${ }^{113}$ had a surer sense of the limitations of Somerset than these American slaves, lawyers, and propagandists. If slavery existed only by virtue of positive municipal law, then the body having power to enact local laws could decide whether to retain slavery or not. Sharp, acutely sensitive to metropolitan infringements of colonial rights, perceived this fact clearly and warned his American coadjutor Anthony Benezet that "with respect to the toler-

109. The Appendix, supra note 96 , at 5 .

110. Massachusetrs SpY, Jan. 28, 1773, vòl. II, at 199, col. 1.

11. Belknap, supra note 101, at 202.

112. See R. Wells, A Few Political Reflections Submitted to the Consideration of the BRItish Colonies 82 (1774). The pamphlet is signed "A Citizen of Philadelphia"; the attribution to Wells appears in T.R. Adams, American Independence: The Growth OF AN IDEA 115 (1965).

113. 1 T. Clarkson, supra note 50, at 287. 
ation of slavery in the colonies, I apprehend the British Parliament has no right to interfere." 114

To restate and expand Sharp's analysis, there are several reasons why Somerset did not disestablish slavery in the American colonies: (1) it did not disestablish slavery even in the metropolis; (2) its sweeping generalizations were paradoxically a source of weakness, for they were neither conceptually hard-edged nor specifically applicable in any jurisdiction outside England; (3) even a lucid opinion disestablishing slavery in Britain would have had only a problematical impact in the colonies, since the imperial constitution was an attenuated arrangement on the eve of the War for American Independence; (4) even if Somerset had explicitly held slavery incompatible with the common law, the question of how far the common law carried over into the colonies was as unsettled as the constitutional structure was. The question of Somerset's force under the imperial constitution became academic with the Declaration of Independence. Even if British courts or Parliament had been inclined to, they could not make policy for the independent American states. Yet Somerset would not down; indeed, its influence in the new American nation remained long after its arguably binding authority had disappeared.

\section{VI}

Mansfield had said that slavery was "so odious, that nothing can be suffered to support it but positive law." In the United States, opponents of slavery interpreted and elaborated on this statement so extensively that they created a quite distinct doctrine, which might be called "neo-Somerset". The new doctrine argued that slavery was so contrary to natural law that it could not legitimately exist unless explicitly established by positive law. Some abolitionists went further, denying that even positive law could establish slavery. Faced with these doctrines, pro-slavery southern jurists were driven first to argue around neo-Somerset, and then to repudiate it altogether. The tension between slavery and natural law was one of the two chief legacies of Mansfield to the American law of slavery. ${ }^{115}$

To trace the constitutional dialogue that engendered neoSomerset, it might be helpful first to outline differing positions in

114. G. Brookes, Friend Anthony Benezet 420 (1937). See also Letter from Granville Sharp to Anthony Benezet, April 21, 1772, quoted in A. Zilversmit, The First EmanciPATION: The Abolition of Slavery in the North 89 (1967).

115. The other, the impact of slavery on conflict of laws doctrine, will be examined in the next section. 
the controversy over slavery. After 1839 , the anti-slavery movement split into three more or less mutually hostile groups, which we shall call the Garrisonians, the moderate constitutionalists, and the radical constitutionalists. ${ }^{116}$ The Garrisonians maintained after 1844 that the United States Constitution supported slavery, and they therefore called on abolitionists to repudiate their allegiance to it and to the American union. From this perspective, they developed a perversely effective defense of slavery's legitimacy in America-in fact, theirs were the most telling proslavery legal and constitutional arguments until the works of John Codman Hurd and Thomas R. R. Cobb appeared in 1858.117 Both the moderate and radical constitutionalists asserted that slavery should be opposed on constitutional grounds and by political means. The radicals, believing that slavery was everywhere illegitimate, argued that the federal government should abolish slavery throughout the union. The moderates, on the other hand, sought only to divorce the federal government from support of slavery and to persuade the states to abolish slavery within their jurisdictions. Moderates denied that the federal government even could interfere with slavery in the states. The defenders of slavery did not suffer from similar fundamental divisions. Over time they moved towards an increasingly militant and comprehensive defense of the universal legitimacy of slavery. These basic positions provided the dynamic of the constitutional controversy over slavery.

The jurisprudential basis of antislavery constitutionalism was a posited distinction between mundane law, that is, law based on human will, and natural law, which was of superior obligation because it was promulgated by God or was a part of the natural order. Drawing on a vigorous though rudimentary philosophy

116. No adequate review of this three-sided debate yet exists. I am preparing a study, tentatively titled The Origins of American Antislavery Constitutionalism, 1760-1846, which hopefully will fill this gap. In the meantime, consult the following for introductions: on the Garrisonians, A. Kraditor, Means and Ends in American Abolitionism 185-217 (1969), and Stewart, The Aims and Impact of Garrisonian Abolitionism, 1840-1860, 15 CIv1L WAR Hist. 197 (1969); on the moderate constitutionalists, D. Dumond, supra note 4, and H. Graham, Everyman's Constitution: Historical Essays on the Fourteenth Amendment, the "Conspiracy Theory", and American Constitutionalism 152-294 (1968); and on the radicals, J. TENBROEK, EQUAL UNDER LAW 41-131 (1951).

117. See T. Cobb, AN Inquiry into the Law of Negro Slavery in the United States of America. To Which is Prefixed, An Historical Sketch of Slavery (Philadelphia ed. 1858); J. Hurd, The LaW of Freedom and Bondage in the United States (I858). The Congressional Globe from 1833 on is, of course, crammed with arguments by Southern spokesmen, but they did not systematically develop a comprehensive proslavery constitutionalism comparable to Cobb's and Hurd's. 
developed by antislaverymen during the Revolutionary era, ${ }^{118}$ antislavery constitutionalists claimed that any human ordinance inconsistent with the "natural foundation of rights" lacked "moral binding force" and was not obligatory unless expressed "with irresistible clearness" by the legislative authority. ${ }^{119}$

The radicals, including the New York editor William Goodell, ${ }^{120}$ the Massachusetts lawyer Lysander Spooner, ${ }^{121}$ and Gerrit Smith, ${ }^{122}$ an upstate New York philanthropist, lawyer, and congressman, insisted that slavery had never been established in America by positive legislation: "[S]lavery in this country had no legal origin, and has continued to exist without law." ${ }^{23}$ All purported statutory recognition of slavery (in, for instance, the Royal African Company charter and the American colonial and state black codes) was too indefinite to overcome the common law guarantees of individual liberty, such as the writ of habeas corpus and the right to jury trial. ${ }^{124}$

Radical antislaverymen considered slavery no more compatible with the common law than with natural law, partly because they assumed the common law embodied the principles of natural justice. In the Representation Granville Sharp had stressed an old common law maxim, Debile fundamentum fallit opus, which in this context might best be translated as "the foundation being defective, the superstructure collapses." Sharp had used it to attack slavery for its origins in kidnapping and rapine. ${ }^{125}$ His American successors, however, regarded slavery's status under common law

118. See LetTer from Granville Sharp, EsQ. of London, to the Maryland Society for Promoting The Abolition of Slavery (1793). See also T. Day, Fragment of an Original Letter on the Slavery of Negroes; Written in the Year 1776, at 32 (1784); E. Hicks, Observations on the Slavery of Africans and Their Descendants 5, 8-9 (1811).

119. Has Slavery in the United States a Legal Basis? I MAss. Q. Rev. 145, 146, 149 (1848), citing Chief Justice Marshall in United States v. Fisher, 6 U.S. (2 Cranch) 358, 390 (I804): "Where rights are infringed, where fundamental principles are overthrown, where the general system of the laws is departed from, the legislative intention must be expressed with irresistible clearness to induce a court of justice to suppose a design to effect such objects." Lysander Spooner has been identified as the author of this essay. C. HAar, ThE Golden AGe of AMERICAN LAw 271 (1965). See also Nelson, The Impact of the Antislavery Movement Upon Styles of Judicial Reasoning in Nineteenth Century America, 87 Harv. L. Rev. $513,528-32$ (1974), for a discussion of the strand of antislavery jurisprudence found in eighteenth century traditions about human rights.

120. W. Goodell, The American Slave Code (1853).

121. L. SPOONER, THE UNCONSTITUTIONALITY OF SLAVERY (1860).

122. Letter from Gerrit Smith to Edmund Quincy, Nov. 23, 1846, quoted in O. FrothINGHAM, GerRIT SMITH: A BIOGRAPHY 201-08 (1878).

123. W. GOODELL, supra note 120 , at 268.

124. L. SPOONER, supra note 121, at 21-32.

125. SHARP, REPRESENTATION, at 145 . 
as the defective fundamentum that rendered the whole structure of slavery unsound.

William Goodell noted that every mainland colonial charter provided in one form or another that the colony's legislative authority did not extend to enacting laws repugnant to the laws of England. Since the common law was a "law" of England, and since (as Goodell read Somerset) Mansfield had held slavery to be contrary to the common law, the colonies could not legally enact slave codes, and slavery could thus have no legitimate origin. ${ }^{126}$

Others pursued a similar analysis. In remarks before a committee of the Massachusetts House of Representatives, Henry B. Stanton, a Bay State lawyer, claimed that "[o]n the principles of the common law, slavery is everywhere null and void. Common law operates as an abolition act whenever it comes in contact with slavery. By it, every slave is free." 127 And in The Power of Congress Over the District of Columbia, the first systematic antislavery constitutional treatise, Theodore Dwight Weld maintained that slavery exists "only by positive legislative act, forcibly setting aside the law of nature, the common law, and the principles of universal justice and right between man and man-principles paramount to all law, and from which alone, law derives its intrinsic authoritative sanction." 128

In arguing this common law point, radical antislaverymen seemingly had the advantage of precedent on their side. The First Continental Congress, in the fifth of its Declarations and Resolves, had stated that "the respective colonies are entitled to the common law of England;" 129 and Chief Justice John Marshall, in a dictum in one of his Circuit Court opinions, had improved on the idea by declaiming: "When our ancestors migrated to America, they brought with them the common law of their native country, so far as it was applicable to their new situation; and I do not conceive that the Revolution would, in any degree, have changed the relations of man to man, or the law which regulated those condi-

126. W. Goodell, supra note 120, at 269-70. See also W. Goodell, VIEws of AMerICan Constitutional Law, In Its Bearing Upon American Slavery 97-102, 142-43 (2d ed. 1845); R. Hildreth, Despotism in America: OR, AN INQUiRY into the Nature, Results, and Legal. Basis of the Slave-Holding System in the United States 193, 203 (1854); L. SPOONER, supra note 121, at 21-31. See generally J. Chickering, " $A n$ American Citizen"-Letrer Addressed to the President of the United States on SLAVERY 4 (1855).

127. Remarks of Henry B. Stanton . . Before the Committee of the House of Representatives of Massachusetts 12 (1837).

128. T. Weld, The Power of Congress Over the District of Columbia 13 (1838).

129. I Journals of the Continental Congress 1774-1789, at 69 (1904). 
tions." ${ }^{130}$ His colleague Joseph Story claimed that the neo-Somerset principle-a slave coming into a free jurisdiction "becomes ipso facto a freeman, and discharged from the state of servitude""pervades the common law" of the northern states. ${ }^{131}$

The radical common law argument, which of course ignored Marshall's proviso "so far as it was applicable to their new situation," was farfetched. Even in the late eighteenth century, Americans recognized that not all of the common law had carried over. In a somewhat ambiguous opinion, the South Carolina Supreme Court stated that though slavery may have existed in derogation of common law, "there is a proviso or exception as to all those parts of [the common law] which were inconsistent with the particular constitutions, cusToms and LAws of this (then) province, which left an opening for this part of the provincial constitution and custom of tolerating slavery . . ."132 In 1834, the United States Supreme Court, speaking through Justice McLean, agreed: "[The common law] was adopted, so far only as its principles were suited to the condition of the colonies; and from this circumstance we see, what is common law in one state, is not so considered in another."133 Finally, Mansfield himself had spoken to this point. "It is absurd that in the colonies they should carry all the laws of England with them. They carry such only as are applicable to their situation."134

Colonial laws, though derived from the same matrix as England's, tended to reflect local social circumstances more than original, unified legal precedents. Different portions of the common law prevailed in different settlements, and there was no effective central expositor of the imperial constitution to harmonize or unify them. Thus, whereas the problem of the carryover of the common law was complex, the antislavery common law argument was so simplistic as to be a parody.

Even if positive law could establish slavery, radicals argued, no positive law had ever purported to do so. They saw a difference between the American black codes, which regulated the incidents

130. Livingston v. Jefferson, 15 Fed. Cas. 660, 665 (No. 8411 ) (C.C.D. Va. 1811).

131. J. STORY, supra note $68, \S 96$.

132. White v. Chambers, 2 S. Car. 70, 74 (1796) (emphasis in original).

133. Wheaton v. Peters, 33 U.S. (8 Pet.) 591, 659 (1834) (copyright case); accord, Town of Pawlet v. Clark, 13 U.S. (9 Cranch) 292, 333 (1834). Zephaniah Swift, in an influential legal treatise, likewise observed that the common law was applicable in American states only "so far as it corresponds with our circumstances and situation." Z. SWIFr, A SYSTEM of the Laws of the State of Connecticut 1-2 (1795). See also id. at 40-44.

134. Ewing, The Constitution and The Empire-from Bacon to Blackstone, in 1 THE Cambridge History of the British Empire: The Old Empire, From the Beginnings to 1783, at 615 (J. Rose et al. eds. 1929). 
of the slavery relation, and a hypothetical act that would have stated: "There is hereby established a relation among men known as slavery, by which one person may own the body or a right to the services of another. This relation is lifelong, alienable, and hereditable through the status of the mother." In the minds of some radicals, only such a statute could have been the positive law that Mansfield had referred to. Theodore Dwight, a revolutionary era Connecticut lawyer, in a formal oration before the old Connecticut Abolition Society in 1794, emphasized the point, which some slave state jurists later conceded: no American jurisdiction had ever formally created slavery by municipal regulation. "Search the statute books of Connecticut, from the date of its Charter to the present moment, and tell me where is the law which establishes such an inhuman privilege." ${ }^{135}$

This argument nearly succeeded in Connecticut a generation later. In Jackson v. Bulloch, ${ }^{136}$ the Connecticut Supreme Court of Errors mused: "Did [slavery] depend entirely upon custom or usage, perhaps it would not be too late to enquire, whether a custom so utterly repugnant to the great principles of liberty, justice and natural right, was that reasonable custom, which could claim the sanction of law."137 Unlike Dwight, though, the Connecticut judges accepted the regulatory statutes as a legitimating source of slavery.

Radicals further maintained that, even if slavery were somehow legitimated by custom or prescription, a positive law of liberty would override any mere "toleration" of slavery. They looked to the Declaration of Rights in the early state constitutions, such as the first article of Virginia's Bill of Rights, drafted by George Mason, which stated " $[\mathrm{t}]$ hat all men are by nature equally free and independent, and have certain inherent rights, of which, when they enter into a state of society, they cannot, by any compact deprive or divest their posterity; namely, the enjoyment of life and liberty, with the means of acquiring and possessing property, and pursuing and obtaining happiness and safety." 138 In an opinion leaning towards antislavery, Virginia's venerable Chancellor George Wythe (Thomas Jefferson's law teacher) ruled "that

135. T. Dimght, An Oration, Spoken Before the Connecticut Society, for the Promotion of Freedom and the Relief of Persons Unlawfully holden in Bondage 10 (1794).

136. 12 Conn. 38 (1837).

137. Id. at 42 (emphasis in original).

138. 7 The Federal and State Constitutions 3818 (F. Thorpe, comp. 1909). This provision was widely imitated in subsequent state constitutions. 
freedom is the birth-right of every human being, which sentiment is strongly inculcated by the first article of our 'political catechism,' the bill of rights ...."139 This argument ultimately failed in Virginia, at least as applied to blacks, ${ }^{140}$ but in Massachusetts it carried the day in the famous "case" of Quock Walker.

The Quock Walker story can be seen as an American counterpart of Somerset, especially in its ambiguity and in the resultant misunderstanding about its impact. There were actually three cases involving the alleged slave status of this black; only one, Commonwealth $v$. Jennison (1781), ${ }^{141}$ is of concern to us here. ${ }^{142}$ At the trial of Walker's purported master, Nathaniel Jennison, for an assault on Walker, Chief Justice William Cushing of the Supreme Judicial Court of Massachusetts charged the jury that "whatever usages formerly prevailed or slid in upon us by the examples of others on the subject, they can no longer exist."143 Rather, he continued, "sentiments more favorable to the natural rights of mankind, and to that innate desire for liberty which heaven, without regard to complexion or shape, has planted in the human breast-have prevailed since the glorious struggle for our rights [the Revolution] began."144 These sentiments had led to the adoption of Article I of the Massachusetts Declaration of Rights (1780), which provided:

All men are born free and equal, and have certain natural, essential, and unalienable rights; among which may be reckoned the right of enjoying and defending their lives and liberties; that of acquiring, possessing, and protecting property; in fine, that of seeking and obtaining their safety and happiness. ${ }^{145}$

From his reading of this provision, Cushing concluded that "slavery is in my judgment as effectively abolished as it can be by the

139. Hudgins v. Wrights, II Va. (1 Hen \& M.) 133, 134 (1806). This is not a quote from Chancellor Wythe, but the Supreme Court of Appeals' summary of the Chancery holding. This decision affirmed the Chancery judgment, but the language quoted in the text was expressly disapproved insofar as it pertained to blacks, who were called an exception to the constitutional provisions. Id. at 141 .

140. See note 139 supra.

141. The Quock Walker cases are unreported. But cf. note 142 infra.

142. For a discussion of these cases, see: G.H. MOORE, supra note 105, at 211-13; Cushing, The Cushing Court and the Abolition of Slavery in Massachusetts: More Notes on the 'Quock Walker Case, 5 AM. J. Legal Hist. 118 (1961); O'Brien, Did the Jennison Case Outlaw Slavery in Massachusetts? 17 WM. \& MARY Q. (3d ser.) 219 (1960); Zilversmit, Quack Walker, Mumbet, and the Abolition of Slavery in Massachusetts, 25 WM. \& MARY Q. (3d ser.) 614 (1968).

143. Cushing, supra note 142, at 133; cf. text and note at note 136 supra.

144. Cushing, supra note 142 , at 133.

145. 3 The Federal and State Constitutions, supra note 138 , at 1889. 
granting of rights and privileges wholly incompatible and repugnant to its existence."146 Jennison was convicted, though on what grounds is uncertain. This case did not of itself abolish slavery in Massachusetts, but it was one of several post-Revolutionary freedom suits of various kinds that either shaped or reflected public sentiment favorable to abolition. ${ }^{\mathbf{1 4 7}}$

Later radicals who adopted the approach of Cushing and Wythe maintained that, because of state constitutional provisions similar to those in the Massachusetts and Virginia declarations, state legislatures lacked power to establish slavery. ${ }^{148}$ It was on this point that the moderates disagreed with them. Moderates conceded the legitimacy of slavery in the states; they accepted the purported compromises of the Constitution, under which slavery was to be fostered or abolished by the states alone, with no interference from the national government.

In the Free Soil platform of 1848, the moderates declared: "Resolved, that slavery in the several States of this Union which recognize its existence, depends upon the State laws alone, which cannot be repealed or modified by the Federal Government, and for which laws that government is not responsible. We therefore propose no interference by Congress with Slavery within the limits of any state." ${ }^{49}$ This doctrine had a libertarian potential as well. Led by Salmon P. Chase, moderates concluded that the national government could neither create nor protect slavery in the territories, the District of Columbia, or on the high seas, and could not constitutionally enact the Fugitive Slave Act of 1793.150 Joshua Giddings, Whig congressman from the Western Reserve of Ohio, summed up this part of the moderate theory in his "Creole Resolutions" of 1842. Denying the federal government's au-

146. Cushing, supra note 142 , at 133.

147. Dean, Judge Louell and the Massachusetts Declaration of Rights, 13 ProceEdings of THE MaSs. Hist. Soc. 299, 304 (1875). See also Belknap, Letters, supra note 102, at 375-442. In particular, see the letters from John Eliot, id. at 383; Samuel Dexter, id. at 385; Thomas Pemberton, id. at 393, E.A. Holyoke, id. at 400. Contra, the letter from James Sullivan, id. at 403 .

148. Has Slavery in the United States a Legal Basis? I MAss. Q. Rev. 273, 277-79 (1848).

149. K. Porter \& D. Johnson, National Party Platforms 1840-1860, at 13 (1960). See also id. at 5 (Liberty Party platform of 1844), and the resolutions of the 1841 Liberty Party Convention of Ohio drafted by Salmon P. Chase, quoted in J. Schuckers, The Life and Public Services of Salmon Portland Chase 48-49 (1874).

150. S. Chase, Reclamation of Fugrtives from Service; an Argument for the Defendant . . I in the Case of . . Jones vs. . . Vanzandt 81-82 (1847); A. Kraditor, supra note 116, at 188-89, quoting Letter from Salmon Chase to Gerrit Smith, May 14, 1842; J. SCHUCKERS, supra note 149, at 74-77, quoting Justice Read's opinion in an unreported fugitive slave case. See generally C. Clemveland, Anti-Slavery Addresses of 1844 and 1845 (1867). 
thority to reclaim certain slaves who, while on a vessel in the coastal slave trade, had mutinied and escaped to a free jurisdiction, Giddings insisted that "slavery . . . is necessarily confined to the territorial jurisdiction of the power creating it" and that, once out of that jurisdiction, the slave relationship dissolved permanently. ${ }^{151}$ This doctrine, undergoing numerous variations during the controversy over slavery in the territories, even won over antiabolitionist Democrats like Senator Stephen A. Douglas. Douglas's "Freeport Doctrine," enunciated in 1858, maintained that the federal government could effectively exclude slavery from the territories simply by not enacting a slave code for them. ${ }^{152}$ Another Democrat, Judge Greene C. Bronson of the New York Court of Errors, had anticipated this view by a decade. Since slavery could not exist where no "positive law" established it, he had said in 1848, "[i]f the owner of slaves removes with, or sends them into a country, state, or territory, where slavery does not exist by law, they will from that moment become free men."153

This premise led moderates of the $1840 \mathrm{~s}$ to formulate the "divorce" doctrine, calling for a total divorce of the federal government from the support of slavery. ${ }^{154}$ In addition to the points just noted, divorce implied nonadmission of new slave states, possibly the abolition of the interstate slave trade, and the establishment of political programs hostile to the welfare of slavery in the states. The latter might have included, for example, refusing to hire slave labor on federal projects and denying State Department assistance to those pursuing claims for slaves lost through the actions of foreign powers. "Divorce" gave way in time to the slogan-doctrine "Freedom national, slavery sectional," a sort of moderate summing-up of neo-Somerset. "Freedom national" became an element of the Republican constitutional posture of the $1850 \mathrm{~s}$, as the party's rebuttal to proslavery efforts to extend the federal government's protection for slavery into the territories.

Antiabolitionists, Garrisonians, and defenders of slavery responded to each point in these moderate and radical arguments. Reasoning from a proto-positivist conception of the law as the command of a human sovereign, they denigrated the place of natural law in earthy courts. Law is, according to the Garrisonian

151. Cong. Globe, 27th Cong., 2d Sess. 342 (1842).

152. The Lincoln-Douglas Debates of 1858 , at 88 (R. Johannsen ed. 1965) [hereinafter cited as DEBates].

153. J. Rayback, Free Soll: The Election of 1848, at 253 (1970).

154. E. Foner, Free Soll, Free Labor, Free Men: The Ideology of the Republican Party Before the Civil W'AR 75-80 (1970). 
lawyer Wendell Phillips, "a rule of civil conduct prescribed by the supreme power of a state, commanding what its subjects are to do, and prohibiting what they are to forbear [sic]." 155 The opponents of neo-Somerset agreed with Justice Levi Woodbury of the United States Supreme Court in his concept of the judicial role:

Whatever may be the theoretical opinions of any as to the expediency of some of these [proslavery] compromises, or of the right of property in persons which they recognize, this court has no alternative, while they exist, but to stand by the Constitution and the laws with fidelity to their duties and their oaths. ${ }^{156}$

Accordingly, they argued that a judge must take the law as given and apply it without reference to the postulates of morality. ${ }^{157}$

In their view, natural law and the odiousness of slavery were irrelevant to the workaday world of the law. In modern terms, they considered the challenge to slavery on natural law grounds nonjusticiable. The Reverend Nathaniel Bouton, an antiabolitionist New Hampshire Congregational minister, even denied the claim of natural law upon private individuals. He asserted that citizens had to obey all temporal laws, irrespective of personal opinions about the dictates of higher law. Squaring statutes with higher law was exclusively for legislators. ${ }^{158}$

In the South, jurists and legal commentators were divided on the question of slavery's origins. Some, like the justices of the Georgia Supreme Court, maintained that parliamentary statutes were the legal basis for slavery. ${ }^{159}$ Others cited the colonial black codes. ${ }^{160}$ Those who did not feel a need to ground slavery in specific statutes ${ }^{161}$ argued that it was justified by "prescriptive right," 162 or insisted, as did the Garrisonians, that "custom" or "usage" had established slavery. ${ }^{163}$ Thus, slavery and Mansfield's

155. W. Phillips, Review of Lysander Spooner's Essay on the Unconstitutionality of Slavery 7 (1847). See also Constilutionality of Slavery, 1 Mass. Q. Rev. 463, 464 (1848).

156. Jones v. Van Zandt, 46 U.S. (5 How.) 215, 231 (1847).

157. Chandler, The Latimer Case, LAw RePORTER 481-94 (1843).

158. N. Bouton, The Good land in Which We live: A Discourse Preached . . on the Day of Public Thanksgiving (1850).

159. Neal v. Farmer, 9 Ga. 555 (1851). This decision was widely received in the South as authoritative on the legitimacy of slavery's origins.

160. Mahoney v. Ashton, 4 Md. (4 Har. \& McH.) 295 (1799).

161. See, e.g., G. SaWyer, Southern Institutes; or, an InQUiry into the Origin and

Early Prevalence of Slavery and the Slave Trade 308, 329 (1858).

162. R. Dabney, A Defense of Virginia 69 (1867) (this is a post-Civil War text).

163. Constitutionality of Slavery, supra note 155 , at 470,477 (1848). 
utterance were reconciled: "by positive law, in this connection," a Garrisonian maintained, "may well be understood customary law as the enactment of a statute." 164

Slavery's apologists were finally driven to repudiating Somerset completely. Though as early as 1797 Maryland Attorney General Luther Martin had condemned Mansfield's opinion as "bending to the policy of the times-Wilks [sic] and Liberty,"165 the principal Southern rejection of Somerset took place late in the antebellum period. Proslavery commentators dismissed it as of little weight upon any principle whatever and as "vacillating, doubting, unusual and ... discreditable."166 Then, with Somerset out of the way, they developed a reverse "Freedom national" argument. They maintained that "what is local and municipal is the abolition of slavery. The states that are now non-slaveholding have been made so by positive statute. Slavery exists, of course, in every nation in which it is not prohibited." ${ }^{67}$ Because slavery existed everywhere except where it was abolished by positive law, deriving its legitimacy from "prevalent views of universal jurisprudence,"168 the status of free and enslaved blacks depended exclusively on municipal legislation.

\section{VII}

Mansfield said in Somerset that the power of a master to seize a slave and transport him for sale out of the realm "must be recognized by the law of the country where it is used. The power of a master over his slave has been extremely different, in different countries.". This statement touched on multifarious questions for conflict of laws doctrine and affected the antislavery debate as much as Mansfield's statement about positive law did. The underlying problem was difficult enough in the context of international public and private law; but it caused even greater complications for the mutual relations of quasi-sovereign states in the American union.

Conflict of laws issues in slavery cases derived from positive law problems, and were at first resolved on the basis of positive law concepts. In the supreme courts of Mississippi, Kentucky, and Louisiana, this trend became evident in cases involving the status

164. Id. at 466-67. See also W. Phillips, supra note 155 , at 85 .

165. $4 \mathrm{H}$. Catterall, supra note 8 , at 54 , quoting Martin's argument in Mahoney v. Ashton, 4 Md. (4 Har. \& McH.) 295 (1799).

166. T. CoBB, supra note 117, at 170; G. SAWYER, supra note 161, at 321-22.

167. J. Thornwell, The State of the Country 12 (1861).

168. R. DABNEY, supra note 162 , at 68 ; J. HURD, supra note 117 , at 225. 
of slaves who returned to a slave state after having been taken by their master to one of the free states or territories carved out of the Northwest Territory. As the Mississippi Supreme Court framed the issue, "[The slaveowners] say, you take from us a vested right arising from the municipal law. The petitioners [slaves] say you would deprive us of a natural right guaranteed by the [Northwest] ordinance and the [Indiana] constitution. How should the Court decide, if construction was really to determine it? I presume it would be in favour of liberty." 169 The Kentucky court agreed, holding on neo-Somerset principles that since slavery was a right existing only by positive law and "without foundation in the law of nature," it would dissolve when the master took his slaves to a free jurisdiction. ${ }^{170}$ The Louisiana court extended this analysis and endorsed the "free for a moment, free forever" principle that antislavery advocates had unsuccessfully tried to get English courts to adopt, though the Louisiana judges were less influenced by English antislavery thought than by the explicit regulation to that effect in the Partidas. ${ }^{171}$

These early Southern cases were anomalous in two respects: the courts adopted neo-Somerset principles without the modification suggested by Grace (the reattachment principle); ${ }^{172}$ and they largely ignored the implications of their holdings for problems in the conflict of laws. This approach did not resolve or even evade conflicts questions; it simply postponed them. As the law of conflicts outgrew its roots in private international law and was used to guide the workings of American federalism, its conceptual categories increasingly shaped the American law of slavery.

Justice Joseph Story, a firm though moderate opponent of slavery and the slave trade, tried to strike a blow at the international slave trade by an extension of neo-Somerset principles into the conflicts area. In a case coming up in the First Circuit, La Jeune Eugenie, ${ }^{173}$ Story declared that the bases of international law were threefold: natural law ("the general principles of right and wrong"), "usages" (custom), and the positive law embodied in treaties and municipal law. ${ }^{174}$ Drawing on the ancient Roman con-

169. Harry v. Decker \& Hopkins, 1 Miss. (Walker) 36,43 (1818).

170. Rankin v. Lydia, 9 Ky. (2 A.K. Marshall) 467 (I820).

171. Lunsford v. Coquillon, 14 Mart. 465 (La. 1824); Marie Louise v. Marot, 9 La. 473 (1835). The Partidas provision is quoted in Delphine v. Deveze, 2 Mart. (n.s.) 650 (La. 1824). This rule was reversed by statute. LA. Acts 1846, c. 189.

172. See text and notes at notes 86-87 supra.

173. United States v. The La Jeune Eugenie, 26 F. Cas. 832 (No. 15,551) (C.C.D. Mass. 1822).

174. Id. at 846 . 
cept of the jus gentium (the law of nations), ${ }^{175}$ Story stated that it included every principle "that may be fairly deduced by correct reasoning from the rights and duties of nations, and the nature of moral obligation." These natural law principles, he said, were enforceable in American courts. On that basis, Story held that the international slave trade was "repugnant to the great principles of Christian duty, the dictates of natural religion, the obligations of good faith and morality, and the eternal maxims of social justice," and "inconsistent with any system of law that purports to rest on the authority of reason or revelation. And it is sufficient to stamp any trade as interdicted by public law, when it can justly be affirmed, that it is repugnant to the general principles of justice and humanity." ${ }^{176}$ Eugenie was significant both because it condemned the international slave trade and because it sweepingly asserted a federal judicial power based on natural law premises as broad as those previously enunciated by Justice Samuel Chase in Calder v. Bull. ${ }^{177}$

This broad approach, however, was too much for Story's brethren. Three years later, the Supreme Court, in an opinion by Chief Justice Marshall, rejected the doctrine and implications of Eugenie without mentioning that decision. In The Antelope, ${ }^{178}$ Marshall rejected the natural law analysis that Story had drawn from the law of nations; held that slavery was founded on captivity in war, which, though unlawful, was "a legitimate result of force"; and concluded that since the sources of international law were limited to "usages" and positive law, the great powers had legitimated the slave trade so far as American jurists were concerned.179 After The Antelope, the natural law component of the jus gentium was no longer normative, and municipal law was consistently the starting point for questions of slavery's legitimacy. ${ }^{180}$ Yet The Antelope did not completely repudiate Somerset; in dictum, Marshall adopted the neo-Somerset principle that slavery was incompatible with natural law and could therefore be established only by positive enactment or clearly defined international custom. ${ }^{181}$

175. See generally BLACK's LAw Dictionary 997 (4th ed. 1951).

176. 26 F. Cas. at 846 .

177. 3 U.S. (3 Dall.) 386 (1798).

178. 23 U.S. (10 Wheat.) 66 (1825).

179. Id. at 120-21.

180. Note, American Slavery and the Conflict of Laws, 71 Colum. L. Rev. 74, 89 (1971) [hereinafter cited as Note, Conflict of Laws].

181. 23 U.S. (10 Wheat.) at 122; see Roper, In Quest of Judicial Objectivity: The Marshall Court and the Legitimation of Slavery, 21 STAN. L. Rev. 532 (1969). 
After The Antelope, conflicts cases in American courts tended to come up not in an international law setting, but rather in situations requiring the accommodation of the laws of one American state to the laws and institutions of another. At this time, the American law of conflicts was undergoing transformation at two levels. At a general level, conflicts law was shifting its basis from the idea of a universal moral obligation to the principle of comitas gentium, as Story had advocated in his Conflict of Laws. ${ }^{182}$ Commentators and judges (Story being the exemplar of both) became hostile to notions of extraterritoriality and ubiquity, especially in questions of status derived from a lex domicilii. ${ }^{183}$ On a more particular level, American conflicts law before 1830 had been premised on interjurisdictional accommodation, in which judges shaped the lex fori to integrate as smoothly as possible with the institutions and policies of the foreign jurisdiction. ${ }^{184}$ After 1830, during the exacerbation of the slavery controversy, American states tended to exalt public policy considerations of the lex fori, and the accommodationist impulse disintegrated.

These general and particular tendencies were obvious in Polydore v. Prince, ${ }^{185}$ a federal district court case in which Judge Ashur Ware of Maine carefully discriminated between a status based on the lex domicilii and the incidents of that status. The latter, he ruled, would not govern slaves in a free state if they were not founded in nature and particularly if they were contrary to the institutions of the forum state. The court, though relying on Somerset, accepted the Grace qualification that status would reattach when the slave returned to a jurisdiction recognizing slavery.

The emergent primacy of the Polydore-comitas gentium approach caused a divergence between Northern and Southern courts that culminated in outright hostility on the eve of the Civil War. In the North, antislavery activists seized upon and sometimes created causes célèbres to move the increasingly sympathetic Northern judiciary to antislavery positions derived ultimately from Somerset principles. Southern courts angrily responded by first narrowing, then repudiating entirely, Somerset's liberating possibilities.

The vehicles for the Northern courts' neo-Somerset approach to

182. J. STORY, supra note $68, \S \S 95-96 a$.

183. Note, Conflict of Lau's, supra note 180, at 90-93.

184. Horowitz, Choice-of-Lau Decisions Involving Slavery: "Interest Analysis" in the Early Nineteenth Century, 17 U.C.L.A.L. Rev. 587 (1970).

185. 19 F. Cas. 950 (No. 11,257 ) (D.C. Me. 1837). On the impact of Polydore on conflicts of law, see R. Graveson, Status in the Common Law 28, 64-67, 105 (1953). 
conflicts problems were cases involving sojourners' slaves (slaves brought into the jurisdiction by and with their master for temporary residence), fugitive slaves, or in transitu slaves (slaves being transported through the forum jurisdiction with or without their master). In each of these cases, antislavery counsel contended that the slave's entry into a free jurisdiction accomplished a liberation that could not be defeated by the lex domicilii through principles of comity.

Massachusetts lawyers made a bold assault on the status of sojourners' slaves in the Med case, Commonwealth v. Aves, ${ }^{186}$ and won a much more stunning victory than they could have expected from the conservative Whig and great antebellum Chief Justice of the Supreme Judicial Court, Lemuel Shaw. Med's case began when a group of Yankee dragons organized the Boston Female AntiSlavery Society. This group included such prominent abolitionists as the Weston sisters (Anne, Caroline, and Maria Weston Chapman), Lydia Maria Child, Henrietta Sargent, and Eliza Follen. Deciding, as they put it, to "disinter the law of Massachusetts" on behalf of slaves coming into the Bay State, ${ }^{187}$ they persuaded Ellis Gray Loring and Rufus Choate to secure a writ of habeas corpus on behalf of a six-year-old black girl, Med, brought by her mistress into Massachusetts for a visit.

In argument, Choate and Loring recited every element of Mansfield's opinion and even some points from Hargrave's argument to demonstrate that Med became free when her mistress voluntarily brought her into Massachusetts and that a Bay State court need not respect the property right claim under the principles of comity. Benjamin R. Curtis, on the other side, suggested to the court that Grace, rather than Somerset, was determinative, dismissing Mansfield's words as "highly figurative and declamatory language."

Chief Justice Shaw was indifferent if not hostile to the antislavery plea of Med's intercessors, but he was even more hostile to the extension of slavery into Massachusetts. He declared that slavery was so repugnant to natural law that it could only be established by positive municipal law. Although he did not regard slavery as contrary to the jus gentium, Shaw stated that Massachusetts would recognize by comity only property rights in things, not in persons.

186. 35 Mass. (18 Pick.) 193 (1836). An excellent account of this case is contained in L. Levy, The LaW of the Commoniealth and Chief Justice Shaw 62-68 (1957).

187. M. Chapman, Right and W'rong in Boston, in 1836. Annual Report of the Boston female Anti-Slavery Society; Being a Concise History of the Cases of the Slave Child, Med 48, 63-71 (1836). 
Thus, the lex domicilii of slavery in Louisiana did not extend into Massachusetts, and a master had no power to compel a slave to return to a slave jurisdiction. The Med decision almost completely absorbed Somerset into American law. The Boston ladies paid a curiously effective tribute to the English precedent by literally renaming the little girl Med Maria Sommersett.

Another dramatic illustration of the disintegration of the accommodationist impulse emerged in a series of cases in two contiguous jurisdictions, one slave (Missouri) and the other free (Illinois). These states had extensive commercial and social intercourse between them. Before 1845 , courts in each of the two states went out of their way to respect the social policies of the other. For example, in Willard $v$. The People, ${ }^{188}$ the Illinois Supreme Court affirmed a slaveowner's right of transit across Illinois to Missouri with his slaves. Meanwhile, in Rachel $v$. Walker ${ }^{189}$ an army officer had taken a slave for four years to Fort Snelling in Wisconsin Territory, which was a free area under the Northwest Ordinance. The Missouri Supreme Court held the slave free on the grounds that only "necessity" and not "interest or convenience" was an adequate ground for tolling the liberation of a sojourner's slave.

After antislavery constitutionalism had had its impact on Northern and Southern courts, the Missouri and Illinois Supreme Courts adopted a posture of increasing mutual hostility, culminating in two cases that discourteously disavowed the accommodationist spirit of Willard and Rachel. In Rodney v. Illinois Central Railroad, ${ }^{190}$ a slaveowner sued a railroad for letting a fugitive slave ride on its train to freedom. The Illinois Supreme Court denied a remedy on the ground that Missouri's toleration of slaveholding was repugnant to Illinois policy. The Missouri Supreme Court, in Scott v. Emerson, ${ }^{191}$ the state level predecessor to Dred Scott, overruled Rachel, holding under identical factual circumstances that the sojourner's slave did not become free. The majority bluntly stated the policy underlying this new posture:

Times are not as they were when the former decisions on this subject were made. Since then not only individuals but states have been possessed with a dark and fell spirit in relation to slavery, whose gratification is sought in the pursuit of measures, whose inevitable consequences must be the overthrow

188. 5 Ill. (4 Scam.) 461 (1843).

189. 4 Mo. 350 (1843).

190. 19 Ill. 42 (1857).

191. 15 Mo. 576 (1852). 
and destruction of our government. Under such circumstances, it does not behoove the state of Missouri to show the least countenance to any measures which might gratify this spirit. ${ }^{192}$

The problem of fugitive slaves was more difficult for American courts than the sojourner issue. In the latter, the master voluntarily assumed some risks in taking his slave to a free jurisdiction. In fugitive cases, moreover, the fugitive slave clause in the United States Constitution considerably complicated the problem of interstate relations. ${ }^{193}$ An early fugitive slave case in the Supreme Court of Michigan Territory, In re Pattinson, ${ }^{194}$ suggests how relatively simple the fugitive problem might have been in American jurisdictions had it not been for the clause. In Pattinson, the master-claimant was a Canadian, and Justice Augustus B. Woodward could dispose of the case on "pure" conflicts grounds. $\mathrm{He}$ reinterpreted Somerset to have held that "a right of property cannot exist in the human species" and maintained that slavery was "in contravention of the rights of human nature." He concluded that to restore slaves to a British master would be to permit the lex domicilii to penetrate free jurisdictions in contravention of their constitutions (here, the Northwest Ordinance) and their public policy.

The fugitive slave clause added a new dimension to conflicts problems between American jurisdictions because, drafted in the passive voice, it did not specify who was to carry the burden of enforcement: "No Person . . . shall . . . be discharged . . . but shall be delivered up . ..." All that was syntactically beyond doubt was that the clause worked a partial modification of Somerset in the American union, preventing a free state from modifying the status of a runaway slave from another state. ${ }^{195}$ The Second Congress, in enacting the Fugitive Slave Act of $1793,{ }^{196}$ tried to settle the question of responsibility by establishing a mechanism, under federal and state auspices, through which slaveowners or their

192. Id. at 586.

193. "No Person held to Service or Labour in one State, under the Laws thereof, escaping into another, shall, in Consequence of any Law or Regulation therein, be discharged from such Service or Labour, but shall be delivered up on Claim of the Party to whom such Service or Labour may be due." U.S. ConsT. art IV, § 2.

194. (Sup. Ct. 1807), in 1 Transactions of the Supreme Court of the Territory of Michigan 1805-1814, at 414-18 (W. Blume ed. 1935).

195. See S. Campbell, The Slave Catchers: Enforcement of the Fugitive Slave Law, 1850-1860, at 26-48 (1968).

196. Act of Feb. 12, 1793, ch. 7, 1 Stat. 302. 
agents could get certificates permitting removal of alleged fugitives. In the particularist phase of American conflicts doctrine, abolitionist lawyers contested the constitutionality of this hybrid machinery.

The first major challenge occurred when James Gillespie Birney and Salmon P. Chase tried to thwart the virtual kidnapping of a nearly white girl, Matilda Lawrence, who had worked as a servant in the Birney household. Birney, a former slaveowner, Alabama state legislator, and agent for the American Colonization Society, had been one of the most spectacular converts to the antislavery cause, while Chase was a rising young Cincinnati lawyer destined to become United States Senator, Secretary of the Treasury, and Chief Justice of the United States. They brought an action in an Ohio Court of Common Pleas to secure a writ of habeas corpus to prevent the girl's seizure under the Fugitive Slave Act. ${ }^{197}$

Their arguments in the case demonstrated how flexible and powerful neo-Somerset could be in American constitutional controversy. Chase began his effort with a skillful, broad restatement of the Somerset view of slavery, claiming that the right to hold a slave "can have no existence beyond the territorial limits of the state which sanctions it, except in other states whose positive law recognises $[s i c]$ and protects it. . . . The moment a slave comes within [a free state] he acquires a legal right to freedom." Chase insisted that slavery violated a natural right to individual liberty, a right given by God, "proclaimed by our fathers, in the declaration of independence, to be selfevident and reiterated in our state constitution as its fundamental axiom, that all men are born 'equally free'." 198 Sandwiched between these broad appeals was a workmanlike construction of the role of state courts and the writ of habeas corpus as guarantors of individual liberty, and an argument on the unconstitutionality of the Fugitive Slave Act. The Matilda case was a noble effort, but it tragically failed to secure the liberty of Matilda herself, who was hustled off by her captors to the impenetrable obscurity of Louisiana or Mississippi slavery.

Recognizing that such questions were beginning to pose an ominous threat to the union, Justice Joseph Story determined to grasp the nettle in an 1842 case designed to force a ruling on the

197. See generally B. Fladeland, James Gillespie Birney: Slaveholder to AboliTIONist 149-54 (1955), on the Matilda case.

198. Speech of Salmon P. Chase, In the Case of the Colored Woman, Matilda 8 , 38 (1837). 
constitutionality of state personal liberty laws. These were a series of statutes, enacted in some Northern states beginning in the 1820 s, that provided procedural safeguards like habeas corpus, jury trial, or the writ de homine replegiando to alleged fugitives. In Prigg v. Pennsylvania, ${ }^{199}$ Story reaffirmed the validity of Somerset by describing slavery as "a mere municipal regulation, founded upon and limited to the range of the [domiciliary state's] territorial laws." $200 \mathrm{He}$ upheld the constitutionality of the federal act, adopted the "historical necessity" thesis that the fugitive slave clause had been a sine qua non for Southern ratification of the federal Constitution, and concluded that the clause voided state acts inconsistent with the 1793 federal statute. He qualified this holding, however, by what he viewed as a large concession to antislavery: state officials were not obligated to assist in the enforcement of the federal law.

Story's concession did not conciliate antislavery opinion in the Northern states, nor did it dispose of slavery-related conflicts questions. As the sectional controversy intensified, Northern courts increasingly denied the extraterritorial effect of the lex domicilii of slavery as Illinois had done. This tendency reached its apogee in two state court decisions that were part of the Northern riposte to Dred Scott. ${ }^{201}$ In Anderson v. Poindexter, ${ }^{202}$ the Ohio Supreme Court held that a slave coming into a free jurisdiction (with the consent of the master) for a temporary sojourn was automatically freed because slavery was "repugnant to reason and the principles of natural law" under Somerset. The court refused to adopt the Grace reattachment principle or to recognize the continuation of slave status under principles of comity.

Lemmon v. The People, ${ }^{203}$ involved not sojourners' slaves, but slaves in transitu. The slaves' mistress was on her way from Virginia to Texas, via the port of New York, and the slaves were in effect being transshipped. The New York Court of Appeals declared them free on Mansfield's principles. The case was potentially a greater jolt to the American federal system than the sojourner cases, which at least involved temporary residency; by ignoring comity arguments, the New York court elevated an antislavery neo-Somerset philosophy above the postulates of Chief Justice

199. 41 U.S. (I6 Pet.) 539 (1842).

200. Id. at 611-12.

201. Scott v. Sandford, 60 U.S. (19 How.) 393 (1857).

202. 6 Ohio St. 623 (1857).

203. 20 N.Y. $562(1860)$. 
Taney's Dred Scott opinion. ${ }^{204}$ The owner appealed the decision to the United States Supreme Court, and antislavery propagandists panicked, fearing that a reversal of the New York judgment would establish slavery itself in the free states. The onset of war aborted this possibility, and Lemmon today is forgotten; but in its brief historical moment it marked the uttermost expansion of the libertarian implications of Somerset.

Southern state supreme courts were not indifferent to these trends. In the accommodationist period of conflict of laws development, some of them had held that a slave taken into a free jurisdiction could not be reenslaved when returned to the domiciliary state; ${ }^{205}$ but in later years Southern courts rejected Somerset in favor of Grace. ${ }^{206}$ This anti-Somerset tendency culminated in the judicial doctrines voiced by Joseph Henry Lumpkin, Chief Justice of the Supreme Court of Georgia, who in 1855 vehemently said: "I utterly repudiate the whole current of decision ... from Somerset's case down ... which hold that the bare removal to a free country ... will give freedom. ... This fungus has been engrafted upon [free state] Codes by the foul and fell spirit of modern fanaticism." 207

Southern Justices on the United States Supreme Court approached the same problem more circuitously but in a way vastly more alarming to those who wished to stop the spread of slavery or to preserve freedom in the Northern states. In Strader v. Graham, ${ }^{208}$ Chief Justice Roger B. Taney, in a majority opinion replete with unsettling dicta hostile to antislavery, held that every state had power to determine the status of persons within its jurisdiction, "except in so far as the powers of the states in this respect are restrained, or duties and obligations imposed on them, by the Constitution of the United States." We do not know how far Taney had thought through the import of this proviso. He may have meant nothing more than that the fugitive slave clause restrained

204. For a contemporary discussion on the political and social atmosphere of the late 1850s, see Reasons for Joining the Republican Party. Reasons of Hon. Samuet A. Foot, Late Judge of the Supreme Court of New York 4 (1855) and T. Parker, The Present Aspect of Slavery in America and the Immediate Duty of the North 20 (1858). 205. Lunsford v. Coquillon, 14 Mart. 465 (La. 1824); Hunter v. Fulcher, 28 Va. 189, 1 Leigh 172 (1829).

206. See, e.g., Graham v. Strader, 44 Ky. (5 B. Mon.) 173 (1844), dismissed for u'ant of jurisdiction, 51 U.S. (10 How.) 82 (1850); Guillemette v. Harper, 4 Rich. 186, 191 (S.C. 1850) (dictum).

207. Cleland v. Waters, 19 Ga. $35,41-42$ (1855).

208. 51 U.S. (10 How.) 82,93 (1850). 
the states from liberating fugitives coming within their borders, not a startling or novel assertion. But lurking within his qualification was the possibility that some clause or construction of the federal Constitution might be held to restrain the power of the free states to repel the intrusion of slavery from without-for example, by being unable to declare sojourners' slaves free. Or worse: conceivably the proslavery majority of the Court might hold that no state could interfere in any way with a master's right of property in his slave. Then all states would be slave states. For Northerners, this possibility was epitomized in a remark widely attributed to Georgia Senator Robert Toombs, who supposedly boasted that he would call the roll of his slaves at the foot of Bunker Hill. ${ }^{209}$

Two events of the mid-1850s convinced antislavery and Free Soil Northerners that neither of these latter possibilities was implausible. The first was the calamity of the Dred $S$ cott $^{210}$ decision, in which Justice Nelson repeated Taney's qualification nearly verbatim; ${ }^{211}$ in which Justice Daniel insisted that Grace, not Somerset, was determinative for American courts on the reattachment of status; ${ }^{212}$ and in which the two Justices (McLean and Curtis) who adverted to Somerset principles favorably were obviously outnumbered. ${ }^{213}$ More to the point, Taney (whose opinion was taken by contemporaries to be for the Court) denied that Congress had power to exclude slavery from the territories, because of the due process clause of the Fifth Amendment. ${ }^{214}$ Though this amendment, under the doctrine of Barron $v$. Baltimore, ${ }^{215}$ was not binding on the states, it took little imagination to see that comparable "law of the land" (due process) clauses of the state constitutions could be construed to have the same effect, or that some other clause of the federal Constitution might be interpreted as a corresponding limitation on state power. For example, if slavery were considered to have a contractual basis, the obligation of contracts clause of article I, section 10, might be held to prohibit state interference with the "contract" between master and slave; or the full faith and credit or privileges and immunities clauses of article IV, sections 1

209. Toombs denied having said this. P. Stovall, Robert Toombs: Statesman, SPEAKER, Soldier, SAGE 119 (1892).

210. Scott v. Sandford, 60 U.S. (19 How.) 393 (1857).

211. Id. at 459 .

212. Id. at 486 .

213. Id. at $\mathbf{5 2 9}, 564$.

214. Id. at 449-52.

215. Barron v. Mayor \& City Coun. of Baltimore, 32 U.S. (7 Pet.) 243 (1833). 
and 2 respectively, might serve to guarantee the power of the slaveowner to exercise his rights in free states. Justice Henry Baldwin, in a concurring opinion in Groves $v$. Slaughter, ${ }^{216}$ had already stated that the privileges and immunities clause protected the rights of slaveowners in this way, though it was not clear that he had considered the problem of slaves in a free state.

Though no one outside the United States Supreme Court could have known it at the time, two of its members, Taney and Campbell, seemed to be moving in the direction suggested by Taney's Strader dictum. Justice Campbell, in the final printed draft copy of his Dred Scott opinion, found it necessary to alter a sentence"Wherever the master is entitled to go, the slave may accompany him, unless prohibited by restrictive state or municipal legislation", -in favor of a lamer revision that omitted the qualification after the word "unless". Perhaps Justice Campbell concluded that the states did not have the restrictive power he had been about to reaffirm. ${ }^{217}$

The Chief Justice, in one of the several antiabolition memoranda that he drew up in his last years, ${ }^{218}$ fervently denounced the antislavery attitudes prevalent in the northern states and asserted that both European nations and free states had an obligation to respect the de jure existence of slavery in the Southern states, and "to render up such a slave found in their territory to his owner in a suit instituted for the purpose of recovering him as property." 19 This remark may be an indication of the way Taney would have been inclined to dispose of the Lemmon appeal. ${ }^{220}$

The second event suggesting that the proslavery repudiation of Somerset might destroy the power of the free states to exclude slavery began with the repeal of the Missouri Compromise by the Kansas-Nebraska Act of $1854 .^{221}$ The sponsor of repeal, Senator Stephen A. Douglas, later stated in defining his doctrine of squatter sovereignty (the people of the territories should decide

216. 40 U.S. (15 Pet.) 449, 515-16 (1841).

217. Campbell's corrected draft is in U.S. National Archives, R.G. 267, appellate case file 3230 (Scott $v$. Sandford).

218. Swisher, Mr. Chief Justice Taney, in Mr. Justice 56 (A. Dunham \& P. Kurland eds. 1964).

219. This unpublished (and in parts illegible) draft, which according to internal evidence was written in 1860, can be found in the "Oddments" file, Roger B. Taney Papers, Library of Congress.

220. See text and notes at notes 203-04 supra.

221. Act of May 30, 1854, ch. 59, 10 Stat. 277. 
whether slavery should be admitted, not the federal government or the states) that he cared not whether slavery "be voted up or voted down." Abraham Lincoln, in the Lincoln-Douglas debates of 1858, pounced on this careless assertion, and on Douglas's role in pushing repeal of the Missouri Compromise. He attempted to link Douglas to a supposed conspiracy with President James Buchanan and Chief Justice Taney to push slavery, not only into all the territories, but into the free states as well. At Springfield, Illinois, on June 16, 1858, Lincoln stated that the Dred Scott majority omitted "to declare whether or not the same Constitution permits a State, or the people of a state, to exclude [slavery]. Possibly, this is a mere omission, but ... who can be quite sure that it would not have been voted down in the one case as it had been in the other?" Emphasizing Justice Nelson's reiteration of the Strader v. Graham dictum, Lincoln went on: "Put this and that together, and we have another nice little niche, which we may, ere long, see filled with another Supreme Court decision, declaring that the Constitution of the United States does not permit a State to exclude slavery from its limits."222 At Galesburg on October 7, 1858, he repeated the anticipated rule as a syllogism, relying on the supremacy clause of article VI:

Nothing in the Constitution or laws of any State can destroy a right distinctly and expressly affirmed in the Constitution of the United States. The right of property in a slave is distinctly and expressly affirmed in the Constitution of the United States. Therefore, nothing in the Constitution or laws of any State can destroy the right of property in a slave. ${ }^{223}$

The appeal of the Lemmon case to the United States Supreme Court seemed to abolitionists just the vehicle that Lincoln and others had predicted would be used to force slavery into the free states. Though the case was never decided, Lincoln and the abolitionists were not in the grip of hysteria when they voiced their warning. Taney and his pro-slavery colleagues might well have resolved the conflicts debate engendered by Somerset by annihilating the entire antislavery position.

222. Debates, supra note 152, at 19. Accord, Cong. Globe, 35th Cong., 2d Sess. 124951 (1859) (remarks of Senator Pugh). See V. Hopkins, Dred Scotr's Case 172 (1951); H. Jaffa, The House Divided: An Interpretation of the Issues in the LincolnDouglas Debates 280-93 (1959).

223. DEBATES, supra note 152 , at 230-31. 


\section{CoNCLUSION}

On the eve of the Civil War, Lord Mansfield's musings on the odiousness of slavery and its requisite base in positive law had caused unanticipated controversies that American judges were not able to resolve. The Somerset opinion, in its American adaptations, was the doctrinal basis both for the radical contention that slavery was everywhere illegitimate per se, existing in defiance of the American Constitution, and for the moderate abolitionist effort to deprive slavery of the protection of the federal government. Together with Blackstone's dicta, the Declaration of Independence, and the Declarations of Right in the state constitutions, Somerset became a basic text of antislavery constitutionalism. Its force proved so compelling that slave-state jurists and commentators were obliged to reverse their earlier acceptance of its premises and repudiate it altogether.

Somerset's attractiveness extended well beyond abolitionist circles. As Northern judges in the state supreme courts adopted neoSomerset implications destroying the extraterritorial force of slave status, Southern jurists, including a majority of the United States Supreme Court, mounted a counteroffensive that, to many reasonable men on the eve of the Civil War, forced slavery into all the territories and boded the destruction of Northern states' antislavery policies. Thus, Somerset principles not only deranged the relationships of the states among themselves; they also affected the posture of the federal government vis-à-vis the states.

The issues raised by Mansfield in Somerset were laid to rest peaceably for England by parliamentary emancipation in 1833; but in the United States, it took nothing less than the bloodiest war in our history and a consequent revision of the American federal and state constitutions to affirm a long dead English judge's saturnine reflection that "slavery is of such a nature, that it is incapable of being introduced on any reasons, moral or political."

\section{ApPENDIX: \\ Variant Somerset Reports}

Cases decided by King's Bench in the late eighteenth century were not officially reported. The justices delivered their opinions orally, and whether their words survived depended on the accident of whether a lawyer or other person was present to take notes. Somerset was preserved in this way. To my knowledge, four 
variant reports purport to be, or may have been, taken down by a person present when Mansfield delivered his judgment on June 22 , 1772. Because they contain significant textual variations, a controversy has arisen among scholars over which should be accepted as the most authentic version. The four are:

1. Lofft 1, 18-19 (1772), quoted in pertinent part at the beginning of this article.

2. An account in the (London) Gentleman's Magazine 293-94 (June 1772). ${ }^{224}$ It was reprinted verbatim at page 110 in The Annual Register . . . for the year 1772 (T. Davison, 1800).

3. An account in 34 Scots Magazine 297 (June 1772). ${ }^{25}$ It was reprinted in Granville Sharp, The Just Limitation of Slavery, in the Laws of God, Compared with the Unbounded Claims of the African Traders and British American Slaveholders, app. 8 (1776), with variations in punctuation and with two insertions that, according to Sharp, were taken from the notes of an unnamed lawyer present at the judgment. This version is also conveniently reprinted in F. Shyllon, Black Slaves in Britain 108-10. ${ }^{226}$

4. An unsigned handwritten document in the Granville Sharp transcripts, New-York Historical Society, captioned

224. "The only question before us is, Is the cause returned sufficient for remanding the slave? If not, he must be discharged. The cause returned is, the slave absented himself, and departed from his master's service, and refused to return and serve him during his stay in England; whereupon, by his master's orders, he was put on board the ship by force, and there detained in secure custody, to be carried out of the kingdom, and sold. So high an act of dominion was never in use here; no master ever was allowed here to take a slave by force to be sold abroad, because he had deserted from his service, or for any other reason whatever. We cannot say the cause set forth by this return is allowed or approved of by the laws of this kingdom; therefore, the man must be discharged."

225. "The only question then is, Is the cause returned sufficient for remanding him? If not, he must be discharged. ... So high an act of dominion must derive its authority, if any such it has, from the law of the kingdom where executed. A foreigner cannot be imprisoned here on the authority of any law existing in his own country: the power of a master over his servant is different in all countries, more or less limited or extensive; the exercise of it therefore must always be regulated by the laws of the place where exercised. The state of slavery is of such a nature, that it is incapable of being now introduced by courts of justice upon mere reasoning or inference from any principles, natural or political; it must take its rise from positive lat; the origin of it can in no country or age be traced back to any other source; immemorial usage preserved the memory of positive law long after all traces of the occasion, reason, authority, and time of its introduction are lost; and, in a case so odious as the condition of slaves, must be taken strictly: the power claimed by this return was never in use here; no master ever was allowed here to take a slave by force to be sold abroad, because he had deserted from his service, or for any other reason whatever; we cannot say the cause set forth by this return is allowed or approved of by the laws of this kingdom, therefore the man must be discharged."

226. See also note 4 supra. 
"Trinity Term 1772 On Monday 22 June 1772 In Banco Regis."227 This document was reprinted, with minor variations in punctuation in Prince Hoare, Memoirs of Granville Sharp, Esq. 89-91 (1820).

There are also two other reports, 98 Eng. Rep. 499 and 20 Howell's State Trials 2, both of which are verbatim copies of the report in Lofft with minor variations in spelling and/or punctuation. Finally, there is an undocumented version in Lord Campbell's Lives of the Chief Justices that is so widely variant from all other versions, and so much at variance with Mansfield's ascertainable sentiments on the subject of slavery, that it must be viewed as spurious. ${ }^{228}$

The modern controversy over which of the four reports is authentic began with the 1966 publication of Jerome Nadelhaft's The Sommersett Case and Slavery: Myth, Reality, and Repercussions. ${ }^{229}$ Opting for the Gentleman's Magazine version, Nadelhaft maintained that Capel Lofft attributed to Mansfield arguments that had been made by Hargrave and Sharp. He concluded that all subsequent antislavery readings of Somerset were based on the distorted Lofft version rather than the actual judgment in the case. Nadelhaft's view is supported by the low opinion of Lofft held by John William Wallace, the bibliographer-historian of the English reporters, who dismissed it as a "book of bad reputation."230 James Walvin, a recent scholarly investigator of slavery in Britain, also endorses Nadelhaft's position. ${ }^{231}$

David Brion Davis and F. O. Shyllon suggest that the Scot's Magazine version may be more authentic than Lofft's. Davis has argued in an unpublished paper ${ }^{232}$ that "it is the most detailed and

227. "The question is, whether the Captain has returned a sufficient Cause for the detainer of Somerset? The Cause returned is, that he had kept him by order of his Master with an intent to send him abroad to Jamaica, there will be Sold, So high an Act of Dominion must derive its force from the Laws of the Country; and, if to be justified here, must be justified by the laws of England.-Slavery has been different in different Ages and States: the exercise of the power of a Master over his Slave must be supported by the Laws of particular Countries; but no foreigner can in England claim a right over a Man: such a Claim is not known to the Law's of England. Immemorial Usage preserves positive Law after the occasion or accident which gave rise to it has been forgotten. And, tracing the subject to natural principles the claim of Slavery never can be supported-The power claimed was never in use here, or acknowledged by the Law. Upon the whole we cannot say the Cause returned is sufficient by the Law, and therefore the Man must be discharged."

228. 3 Lord Campbell, The Lives of the Chief Justices of England 316-18 (1873).

229. 51 J. Negro Hist. 193 (1966).

230. J. Wallace, supra note 28 , at 452 .

231. J. WaLvis, supra note 31 . at 127 .

232. Davis. Antislare'y and the Comflict of Laus, to be published in 1975 as ch. X of D. 
the most consistent with Mansfield's known views (Mansfield, or William Murray, was the son of a Scottish peer; at a time when Scots were less than popular in England, it is conceivable that a Scottish reporter would pay closer attention to the actual words of a countryman who had risen to such an exalted station). In short, the phrases in Howell and in the NYHS manuscript may be a somewhat garbled version of the text in The Scots Magazine." Furthermore, Shyllon champions this version because it was the one that Sharp chose to reprint in his Just Limitation, because it "is identical with the report of Mansfield's speech which appeared in the newspapers a day or two after judgment was given," and because Sharp employed a shorthand reporter to take down Mansfield's words. ${ }^{233}$

None of these scholars prove that their choice is the probable one; they prove only possibility, which they support by the inferences already noted. Their inferences are offset, however, by several countervailing considerations. The newspaper and magazine reports are unsigned. A historian must be cautious about relying on anonymous documents, especially when the document conflicts with an alternate account by an identified witness (Lofft) who was a trained expert in the subject he was reporting on.

And more can be said for the Lofft version. Lofft claimed that if he erred in reporting, it was on the side of inclusiveness rather than abbreviation; that he often tried to report verbatim in the interests of verisimilitude; and that his version could be checked against the recollection of contemporaries. He used shorthand for most of his notes and stated that in his reports "you will find the judgments exact in form, the reasons and principles entire, their force, dependence, and connexion preserved . . .."234 Admittedly, these claims are self-serving and cannot be accepted without collateral support. But several somewhat persuasive bits of collateral support do exist.

One confirmation of Loff's accuracy, though qualified, was provided by a person who was in a position to check on what Mansfield had stated, and whose credibility is enhanced by his deep hostility to the statements. Samuel Estwick wrote his Considerations on the Negroe Cause (1772) ${ }^{235}$ as a public legal argument on behalf

Davis, The Problem of Slavery in the Age of Revolutron, 1770-1823. Quoted by permission of Professor Davis.

233. F. Shyllon, supra note 4, at 110. Shyllon does not document his implication that a shorthand reporter actually did take down Mansfield's judgment.

234. Preface to Lofft at ix-x.

235. See text and note at note 61 supra. 
of the West India Interest. In his third edition (1788) he reprinted the Somerset opinion in full as reported by Lofft and stated that it was "said to be the substance of Lord Mansfield's speech."236 Had he wished to controvert the accuracy of Lofft's report, with its harsh condemnation of slavery, we may assume that he would have done so there.

Another oblique endorsement of Lofft was offered by Mansfield himself, who had occasion to comment on contemporaneous interpretations of Somerset thirteen years after it was delivered. Lofft's first edition, a folio, was published in 1776; an octavo edition was brought out in 1790. In 1785, when the folio edition had been in circulation for nine years, Mansfield heard arguments in the case of Rex $v$. Inhabitants of Thames Ditton, discussed in the body of this paper. ${ }^{237}$ In the course of dialogue with counsel, Mansfield corrected what he thought were two misinterpretations of the Somerset holding, but did not claim that Lofft had misquoted him. Here too we may assume that Mansfield would have taken the opportunity to set the record straight if he thought that Lofft had misrepresented his oral opinion.

None of this proves conclusively that Lofft wrote down Mansfield's words verbatim. Barring the unexpected appearance of a holograph or other manuscript of Mansfield's orally delivered opinion, ${ }^{238}$ the question of what Mansfield really said will never be resolved. But on the basis of presently available evidence, Lofft's version is more acceptable to the historian than its competitors. Justice Brandeis once remarked that "in most matters it is more important that the applicable rule of law be settled than

236. S. Estwick, supra note 61 , at vii (3d ed. 1788). Estwick, however, seems to have changed his mind. Sharp said that Estwick in his second edition, published in 1773, reprinted the Scots Magazine version rather than the Lofft version. See G. Sharp, The Just Limitation of Slavery in the Laws of God, Compared with the Unbounded Claims of the African Traders and British American Slaveholders 65 (1776). I refer to Estwick's third edition in the text because I assume it represents his final opinion.

237. See text and note at note 79 infra.

238. Such a manuscript may once have existed. F. Shyllon, supra note 4, at 108 , quoted, The Morning Chronicle, June 23, 1772, as reporting that Mansfield spoke from "a written speech, as guarded, cautious, and concise, as it could possibly be drawn up." Nearly all Mansfield's personal papers, however, were destroyed by the Gordon rioters in 1780. Correspondence with English archivists has failed to turn up such a manuscript or record of a manuscript in the following: 1) Granville Sharp papers, Hardwicke Court, Gloucester (letter from Col. Arthur B. Lloyd-Baker to the author, March 22, 1974); 2) Lincoln's Inn Library, London (letter from R. Walker to the author, May 16, 1974); 3) National Register of Archives, Scotland (letter from Barbara Horn to the author, May 14, 1974); 4) Royal Commission on Historical Manuscripts, London (letter from Elizabeth Danbury to the author, May 1, 1974); 5) Granville Sharp Letterbook, Minster Library, York (letter from James Walvin to the author, March 27, 1974). 
that it be settled right," 239 and something of the spirit of this remark is pertinent here.

Finally, the whole dispute is of only limited relevance. There were after all, really two Somerset opinions: Mansfield's actual words, whatever they were, which may have been preserved in the variant newspaper and legal reports; and the "abolitionists' Somerset," the opinion as understood by Justice Best, the poet Cowper, and the American abolitionists. The latter version, though fictive, proved more influential, especially as the American neo-Somerset. It took on an existence of its own. It is pointless, even if correct, to maintain, as Nadelhaft, Walvin, and Shyllon have, that this neoSomerset does not correspond to the real opinion. Never was the old English maxim more true: Communis error facit jus-common error makes the law. Men believed that Mansfield had held slavery inconsistent with the British constitution, and they acted on that belief. In this sense, William Holdsworth's judgment, ${ }^{240}$ pronouncing the abolitionist reading of Somerset to be "substantially correct," is still valid.

239. Burnet v. Coronado Oil \& Gas Co., 285 U.S. 393, 406 (1932) (Brandeis, J., dissenting).

240. See text and note at note 85 supra. 